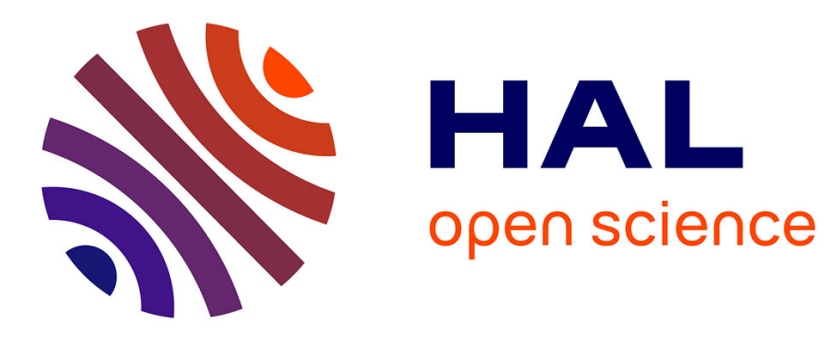

\title{
Accurate characterization of pure silicon-substituted hydroxyapatite powders synthesized by a new precipitation route
}

David Marchat, Maria Zymelka, Cristina Coelho, Laurent Gremillard, Lucile Joly-Pottuz, Florence Babonneau, Claude Esnouf, Jérome Chevalier, Didier Bernache-Assollant

\section{To cite this version:}

David Marchat, Maria Zymelka, Cristina Coelho, Laurent Gremillard, Lucile Joly-Pottuz, et al.. Accurate characterization of pure silicon-substituted hydroxyapatite powders synthesized by a new precipitation route. Acta Materialia, 2013, 9 (6), pp.6992-7004. 10.1016/j.actbio.2013.03.011 . hal00835892

\section{HAL Id: hal-00835892 https://hal.science/hal-00835892}

Submitted on 20 Jun 2013

HAL is a multi-disciplinary open access archive for the deposit and dissemination of scientific research documents, whether they are published or not. The documents may come from teaching and research institutions in France or abroad, or from public or private research centers.
L'archive ouverte pluridisciplinaire HAL, est destinée au dépôt et à la diffusion de documents scientifiques de niveau recherche, publiés ou non, émanant des établissements d'enseignement et de recherche français ou étrangers, des laboratoires publics ou privés. 
Accurate characterization of pure silicon-substituted hydroxyapatite powders synthesized by a new precipitation route

David MARCHAT ${ }^{1 *}$, Maria ZYMELKA ${ }^{1}$, Cristina COELHO ${ }^{2}$, Laurent GREMILLARD ${ }^{3}$, Lucile JOLY-POTTUZ ${ }^{3}$, Florence BABONNEAU ${ }^{4}$, Claude ESNOUF ${ }^{3}$, Jérôme CHEVALIER $^{3}$, Didier BERNACHE-ASSOLLANT ${ }^{1}$

${ }^{1}$ Ecole Nationale Supérieure des Mines, CIS-EMSE, CNRS:FRE3312, F-42023 158 cours Fauriel Saint-Etienne cedex 2

${ }^{2}$ Institut des Matériaux de Paris Centre, FR 2482, Université Pierre et Marie Curie and CNRS Collège de France, 11 place Marcelin Berthelot 75005 Paris, France

${ }^{3}$ Université de Lyon, INSA-Lyon, MATEIS Laboratory UMR CNRS 5510, Villeurbanne F69621, France

${ }^{4}$ Laboratoire de Chimie de la Matière Condensée de Paris, CNRS, Université Pierre et Marie Curie and CNRS, Collège de France, 11 place Marcelin Berthelot 75005 Paris, France.

E-mail addresses : marchat@emse.fr (David Marchat)*, mzymelka@emse.fr (Maria Zymelka), cristina.coelho@upmc.fr (Cristina Coelho), laurent.gremillard@insa-lyon.fr (Laurent Gremillard), lucile.joly-pottuz@insa-lyon.fr $\quad$ (Lucile Joly-Pottuz), florence.babonneau@upmc.fr (Florence Babonneau), claude.esnouf@insa-lyon.fr (Calude Esnouf), jerome.chevalier@insa-lyon.fr (Jérôme Chevalier), bernache@emse.fr (Didier Bernache-Assollant),

*Corresponding author: Phone: 0033 (0)4 774997 01, Fax: 0033 (0)4 77499694

Address: Ecole Nationale Supérieure des Mines, Centre Ingénieurie et Santé, 158 cours Fauriel 42023 Saint-Etienne, cedex 2, France. 


\section{Abstract}

This paper presents a new aqueous precipitation method to prepare silicon-substituted hydroxyapatites $\mathrm{Ca}_{10}\left(\mathrm{PO}_{4}\right)_{6-\mathrm{y}}\left(\mathrm{SiO}_{4}\right)_{\mathrm{y}}(\mathrm{OH})_{2-\mathrm{y}}\left(\mathrm{V}_{\mathrm{OH}}\right)_{\mathrm{y}}(\mathrm{SiHAs})$ and details the characterization of powders with varying $\mathrm{Si}$ content up to $\mathrm{y}=1.25 \mathrm{~mol} \mathrm{~mol}_{\mathrm{SiHA}}{ }^{-1}$. X-ray diffraction (XRD), transmission electron microscopy (TEM), solid-state nuclear magnetic resonance (NMR) and Fourier transform infrared (FTIR) spectroscopy were used to accurately characterize samples calcined at $400^{\circ} \mathrm{C}$ for $2 \mathrm{~h}$ and $1000^{\circ} \mathrm{C}$ for $15 \mathrm{~h}$. This method allows for synthesizing monophasic SiHAs with controlled stoichiometry. The theoretical maximum limit of incorporation of Si into the hexagonal apatitic structure is $y<1.5$. This limit depends on the $\mathrm{OH}$ content in the channel, which is a function of the Si content, temperature and atmosphere of calcination. These results, particularly those from infrared spectroscopy, express serious reservations about the phase purity of SiHA powders, pellets or scaffolds prepared and biologically evaluated in the literature.

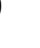

0

6 Keywords: biomaterials; silicon-substituted hydroxyapatite; precipitation method, infrared 7 spectroscopy, NMR spectroscopy. 48 


\section{Introduction}

According to the literature, silicon-substituted hydroxyapatite (SiHA) is a highly promising material in the field of bioactive bone substitutes and bone tissue engineering. It is now wellestablished that silicon plays an important role in the early stage of cartilage and bone growth [1-4]. Soluble silicon species have been shown to stimulate spontaneous calcium phosphate precipitation (i.e. the mineral bone phase) [5] and to increase bone mineral density [6]. Moreover, silicon has been reported to have a positive influence on the synthesis of type I collagen by human osteoblast cells (MG-63 cell line) in vitro [7]. Thereby, it is expected that silicon could enhance the hydroxyapatite (HA) bioactivity [8, 9], and silicon-substituted hydroxyapatites (SiHAs) have become a subject of great interest in bone repair. The SiHA structure corresponds to the substitution of phosphate ions $\left(\mathrm{PO}_{4}{ }^{3-}\right)$ by silicate ions $\left(\mathrm{SiO}_{4}{ }^{4-}\right)$ into the HA crystal structure. Different mechanisms for charge compensation have been suggested $[8,10,11]$. The most cited one was proposed by Gibson et al. with the creation of anionic vacancies at $\mathrm{OH}^{-}$sites $[8,12]$. This mechanism leads to silicon-substituted hydroxyapatites with the general formula $\mathrm{Ca}_{10}\left(\mathrm{PO}_{4}\right)_{6-\mathrm{y}}\left(\mathrm{SiO}_{4}\right)_{\mathrm{y}}(\mathrm{OH})_{2-\mathrm{y}}\left(\mathrm{V}_{\mathrm{OH}}\right)_{\mathrm{y}}$, where $\mathrm{y}$ represents the molar number of silicate groups introduced into the apatitic structure $(0 \leq \mathrm{y} \leq$ 2) and $\mathrm{V}_{\mathrm{OH}}$ stands for vacancies maintaining the charge balance. The incorporation of Si into the HA structure in solid solution, i.e. without the formation of other phases, seems to be limited. However, the value and the origin of this limitation are still not known, with for instance the following values: $5 \mathrm{wt} \%\left(\approx 1.7 \mathrm{~mol}_{\mathrm{Si}} \mathrm{mol}_{\mathrm{SiHA}^{-1}}{ }^{-1}[13-15], 4 \mathrm{wt} \%\left(\approx 1.4 \mathrm{~mol}_{\mathrm{Si}}\right.\right.$ $\left.\operatorname{mol}_{\mathrm{SiHA}}{ }^{-1}\right)[16,17], 3.1 \mathrm{wt} \%\left(\approx 1.1 \mathrm{~mol}_{\mathrm{Si}} \mathrm{mol}_{\mathrm{SiHA}}{ }^{-1}\right)[18], 2 \mathrm{wt} \%\left(\approx 0.7 \mathrm{~mol}_{\mathrm{Si}} \operatorname{mol}_{\mathrm{SiHA}}{ }^{-1}\right)[11$, 19], $1.0 \mathrm{wt} \%\left(0.36 \mathrm{~mol}_{\mathrm{Si}} \mathrm{mol}_{\mathrm{SiHA}}{ }^{-1}\right)$ [20] or $0.28 \mathrm{wt} \%\left(0.1 \mathrm{~mol}_{\mathrm{Si}} \mathrm{mol}_{\mathrm{SiHA}}{ }^{-1}\right)$ [21]. Additionally, it has been suggested that the concentration of $0.8 \mathrm{wt} \%$ of $\mathrm{Si}\left(\approx 0.28 \mathrm{~mol}_{\mathrm{Si}} \mathrm{mol}_{\mathrm{SiHA}}{ }^{-1}\right)$ is optimal to induce the development of important bioactivity [22-24]. A value of $2.2 \mathrm{wt} \%$ of $\mathrm{Si}$ was also reported by Thian et al. [25]. Unfortunately, in spite of extensive studies in recent 
years, these results remain heterogeneous, confusing and sometimes misleading. For instance, Hing et al. revealed faster bone apposition and improved adhesion and proliferation of osteoblast-like cells for SiHA compared to stoichiometric HA [23, 26], whereas Palard et al. found no significant difference in the behavior of MG-63 osteoblast-like cells between pure HA and SiHA pellets (three compositions: $\mathrm{y}=0.2,0.4$ and $0.6 \mathrm{~mol}_{\mathrm{Si}} \mathrm{mol}_{\mathrm{SiHA}}{ }^{-1}$ ) [27]. Recent critical analyses of the published results regarding SiHAs have highlighted the lack of experimental evidence which could explain the real effects of Si substitution on biological activity in a biological environment $[28,29]$. In particular, it has been criticized that the physico-chemical characterizations of SiHA bioceramics are not detailed (purity, solubility, rate of incorporation of $\mathrm{Si}$ inside the crystal lattice, etc.). Therefore, the available data do not provide sufficient information to establish the origin of the improved biological performance of SiHA: (i) a direct effect of SiHA by Si release, (ii) an indirect effect of $\mathrm{SiHA}$ by changes in the physico-chemical properties of HA due to $\mathrm{Si}$ substitution (microstructure, superficial chemistry, topography, etc.) or (iii) an effect of second phases (crystalline and/or amorphous). According to Boanini et al., the term "ion-substituted" is quite often used without any experimental proof regarding the incorporation of ions inside the crystal lattice of calcium orthophosphates [28]. The unclear bioactivity of SiHA ceramics could be explained by variations in the phase composition. The first evidence for this was provided by the few accurate analyses available in the literature which show that SiHA powders can contain crystallized [16, 30-35] and amorphous [16, 34, 36-38] impurities. The study by Kanaya et al. is representative of the characterization problems of SiHA samples [38]. Indeed, while the Xray diffraction patterns show only the characteristic lines of the HA phase (PDF: 09-432), the ${ }^{29} \mathrm{Si}$ MAS NMR spectrum revealed that only $10 \%$ of Si was incorporated into the HA lattice; the rest was on the particle surface in the form of polymeric silicate species [38]. An equivalent observation was made by Gasquères et al. [16]. Most studies do not evidently show 
the purity of their SiHA samples (powders, pellets or scaffolds) [8, 9, 19, 21-24, 26, 27, 3958]. They generally provide an imprecise physico-chemical characterization with assumptions based on X-ray diffraction patterns or incomplete infrared band assignment $[8,9,19,22,32$, 36, 39, 59-61]. Moreover, infrared vibrations at 692, 840, 890 and $945 \mathrm{~cm}^{-1}$, detected on an SiHA sample containing $1.6 \mathrm{wt} \% \mathrm{Si}\left(1200^{\circ} \mathrm{C}\right.$ for $\left.2 \mathrm{~h}\right)$, were attributed without evidence by Gibson et al. to the substitution of $\mathrm{SiO}_{4}$ for $\mathrm{PO}_{4}$ into the HA lattice $[8,12]$. Unfortunately, this article set the standard for SiHA analysis by infrared spectroscopy and has been widely cited to prove the purity of SiHA powders synthesized using Gibson's method $[9,23,39,40,43$, $44,46,47,53,57]$ or displaying the same new infrared bands [14, 32, 36, 48, 50, 54, 62].

Several methods are used to prepare Si-substituted hydroxyapatites (SiHAs), such as the sol-gel route [48], resuspension processes [20, 33, 34, 63-66], solid state reactions [10, 67], hydrothermal techniques [17, 68, 69], mechanochemical methods [70], magnetron sputtering [14], pulsed laser deposition [51, 71], electrophoretic deposition [72] and precipitation from aqueous solutions. Aqueous precipitation methods are the most often described and set up in the literature. Two different procedures are used to produce Si-HA from aqueous solutions: (i) the acid-base neutralization $[8,9,16,19,23,30,35,37,39,46$, $47,49,50,53,56,57,73-75]$, and (ii) the use of phosphorus and calcium salts $[13,21,32,36$, $37,60,74,76,77]$. Generally, far less attention has been devoted to the silicon reagent. Two organic compounds are mainly used as a source of silicate ions: tetraethylorthsilicate (TEOS, $\left.\mathrm{Si}\left(\mathrm{OC}_{2} \mathrm{H}_{5}\right)_{4}\right)$ and tetraacetoxysilane (TAS, $\left.\mathrm{Si}\left(\mathrm{COOCH}_{3}\right)_{4}\right)$ which are not miscible in water. Powders synthesized through these methods are poorly crystallized and often contaminated by second phases (e.g. $\alpha$ and $\beta$-Tricalcium phosphate, amorphous phase, silicocarnotite $[16,19$, $30,31,36-38,49,59,60,63,64,67,74,76])$ or undesired ions like $\mathrm{Mg}$ [56], S [77] or $\mathrm{Na}$ [78, 79]. 
In order to correctly describe the physical, chemical and biological properties of SiHAs and to compare them to routinely implanted HA and $\beta$-TCP, well-characterized pure SiHAs powders first need to be prepared. Therefore, this work was devoted to the development of a new route to synthesize monophasic SiHA powders with controlled stoichiometry. To this purpose, a solution of soluble silicate was first prepared from TEOS via a sol-gel route, and then accurate powder analysis was carried out by means of ICP/AES, Xray powder diffraction, Rietveld refinement, high resolution electron transmission microscopy (HR-TEM) with energy dispersive spectroscopy (EDS) as well as infrared (FT-IR/ATR) and solid-state NMR spectroscopy. Two $\mathrm{pH}$ levels of precipitation were studied, as well as six $\mathrm{Si} / \mathrm{P}$ molar ratios.

\section{Materials and methods}

\subsection{Powder synthesis}

HA and SiHA powders were prepared through an aqueous precipitation method using a fully automated apparatus. A diammonium hydrogen phosphate aqueous solution $\left(\left(\mathrm{NH}_{4}\right)_{2} \mathrm{HPO}_{4}\right.$, 99\%, Merck, Germany), and, if applicable, an alkaline silicate solution were added to a calcium nitrate solution $\left(\mathrm{Ca}\left(\mathrm{NO}_{3}\right)_{2}, 4 \mathrm{H}_{2} \mathrm{O}, 99 \%\right.$, Merck, Germany) using peristaltic pumps. The reaction was performed under an argon flow (4.8, AirLiquide) to prevent any excessive carbonation of precipitates. The $\mathrm{pH}$ of the suspension was adjusted by the addition of a $28 \%$ ammonia solution (Merck, Germany) by means of a pH stat (Hanna Instruments), and the temperature was controlled and regulated automatically with an external T-probe. The suspension was continuously stirred and refluxed. After complete introduction of the solutions, the suspension was matured for $24 \mathrm{~h}$, and then filtered under vacuum. Finally, the precipitates were dried at $70^{\circ} \mathrm{C}$ overnight.

The solution of soluble silicates was prepared from tetraethylorthosilicate (TEOS $\geq 99 \%$, Aldrich, Germany) via a sol-gel route. The original step consisted of the preparation of 
a silica gel through the hydrolysis and condensation of this precursor. First, the alkoxide groups (Si-OEt) of TEOS were hydrolyzed to silanol groups $(\mathrm{Si}-\mathrm{OH})$. The reaction was catalyzed by a nitric acid aqueous solution $\left(7.510^{-3} \mathrm{M}\right)$. This generates a considerable amount of monomers (Si-OH), which aggregate and form a colloidal suspension called the "sol". This reaction, based on Klein et al. [80], was carried out by maintaining the molar ratio of TEOS/ethanol/acidified water at $1.0 / 8.5 / 4.0$ and the solution at $25^{\circ} \mathrm{C}$ in an ambient atmosphere. Second, the condensation of the silanol or alkoxide groups was initiated by increasing the solution $\mathrm{pH}$ to a basic level, about $\mathrm{pH} 8$, with a few drops of pure $28 \%$ ammonia solution (Merck, Germany). This reaction creates siloxane bridges (Si-O-Si), leading to the formation of a silica gel. The gelation reaction was continued for about $12 \mathrm{~h}$ at $25^{\circ} \mathrm{C}$. Finally, a solution of soluble silicates was obtained by depolymerization of the silica gel. This was achieved through the nucleophilic attack of siloxane linkages (Si-O) by hydroxide ions in pure $28 \%$ ammonia solution $(\mathrm{pH}>11)$. After filtration through a Millipore filtration unit (Magma nylon, $0.8 \mu \mathrm{m}$ ), the soluble silicate ion concentration of these solutions was measured by means of an ion-exchange chromatography system (DIONEX DX-500) equipped with $\mathrm{SiO}_{4}{ }^{4-}$ ion exchange column (AS4A) with a UV/Vis detector (410 nm). The soluble silicate ion concentration in these solutions was, on average, $1076 \pm 34 \mathrm{ppm}(\mathrm{n}=14$ solutions). This value is a function of the preparation process (e.g. hydrolysis, condensation and depolymerization reactions). Thereby, the volume of the solutions of soluble silicates was adjusted for each synthesis.

A pure HA powder $\mathrm{Ca}_{10}\left(\mathrm{PO}_{4}\right)_{6}(\mathrm{OH})_{2}$ was first prepared to be used as a reference material for further SiHA syntheses and analyses. This was obtained at a $\mathrm{pH}$ and temperature of precipitation of 9.5 and $50^{\circ} \mathrm{C}$, respectively, with a maturation time of $24 \mathrm{~h}$, and a reagent (Ca/P) molar ratio equal to $10 / 6$. 
The reagent ratios used to prepare the SiHA powders were calculated by assuming,

173 first, the general formula $\mathrm{Ca}_{10}\left(\mathrm{PO}_{4}\right)_{6-\mathrm{y}}\left(\mathrm{SiO}_{4}\right)_{\mathrm{y}}(\mathrm{OH})_{2-\mathrm{y}}\left(\mathrm{V}_{\mathrm{OH}}\right)_{\mathrm{y}}$ and, second, a constant molar

ratio $\mathrm{Ca} /(\mathrm{P}+\mathrm{Si})$ equal to $10 / 6$. The volume of the calcium and phosphate aqueous solutions was fixed at $500 \mathrm{~mL}$ and $250 \mathrm{~mL}$, respectively. Table 1 summarizes the amount (mol) of Ca, $\mathrm{P}$ and $\mathrm{Si}$ used for each (Si)HA powder prepared with $y$ equal to $0,0.25,0.50,0.75,1.00,1.25$; designated hereafter as $\mathrm{HA}, \mathrm{Si}_{0.25} \mathrm{HA}, \mathrm{Si}_{0.50} \mathrm{HA}, \mathrm{Si}_{0.75} \mathrm{HA}, \mathrm{Si}_{1.00} \mathrm{HA}$ and $\mathrm{Si}_{1.25} \mathrm{HA}$, respectively. Precipitations were achieved at $50^{\circ} \mathrm{C}$ for $24 \mathrm{~h}$ of maturation time, according to the preliminary tests performed on pure HA. Two parameters of precipitation were examined, the $\mathrm{pH}$ of precipitation and the stoichiometric number $y$, i.e., the amount of silicate theoretically incorporated into the apatite structure. Precipitations were conducted either at $\mathrm{pH} 9.5$, previously established for HA synthesis, or at $\mathrm{pH} 10.80 \pm 0.05$. The former was chosen according to phosphate and silicate speciation curves, in order to have $\mathrm{HPO}_{4}{ }^{2-}[81]$ and $\mathrm{H}_{3} \mathrm{SiO}_{4}{ }^{-}$ions [82] in solution as the main phosphate and silicate species, respectively. The studied parameters are listed in Table 1.

The as-synthesized powders were heated under air using an alumina crucible. Aliquots of each sample were calcined both at $400^{\circ} \mathrm{C}$ for $2 \mathrm{~h}$ (designated hereafter as "raw powders"), in order to remove synthesis residues, and at $1000^{\circ} \mathrm{C}$ for $15 \mathrm{~h}$ under air according to ISO norm 13779-3 in order to characterize powders with a well-defined structure. The heating and cooling rate was fixed at $4^{\circ} \mathrm{C} \mathrm{min}^{-1}$.

\subsection{Powder characterization}

\subsubsection{X-ray powder diffraction and Rietveld refinement}

Crystalline phases were identified by means of a Siemens D5000 $\theta / 2 \theta$ X-ray diffractometer (XRD) using $\mathrm{CuK} \alpha$ radiation and operating at $40 \mathrm{kV}$ and $20 \mathrm{~mA}$. XRD patterns were first collected over the $2 \theta$ range of $10-60^{\circ}$ at a step size of $0.03^{\circ}$ and counting time of 4 s per step in order to determine the phase composition. Crystalline phases detected in the patterns were 
identified by comparison to standard patterns from the ICDD-PDF (International Center for Diffraction Data-Powder Diffraction Files). In addition, high resolution XRD scans were obtained on calcined powders from $10^{\circ}$ to $120^{\circ}$ in $0.02^{\circ}$ steps with a counting time of $10.5 \mathrm{~s}$ per step. These patterns were used to calculate the lattice parameters and the crystalline size by full pattern matching. In this mode, the positions of the diffraction peaks and the systematic extinctions are calculated from the cell parameters and the space group. The intensities of the lines are adjusted by the refinement program and not calculated from the atomic positions. The refinements were performed using the space group of the HA structure P63/m (PDF 09-432) by means of the Topas software (Bruker, Germany). The initial cell parameters were taken as $a=9.42 \AA$ and $c=6.88 \AA$.

The evolution of the crystallinity of the samples after calcination at $1000^{\circ} \mathrm{C}$ for $15 \mathrm{~h}$ was evaluated by means of the full width at half maximum (FWHM) of the (211) peak at $2 \theta=31.8^{\circ}$, as it had the highest intensity and minimal overlap with neighboring peaks.

\subsubsection{Infrared spectroscopy}

Fourier transform infrared (FT-IR) measurements were carried out with the use of a MIR TF VERTEX 70 Spectrometer by means of the ATR system. The spectra were recorded over the range of 450-4000 $\mathrm{cm}^{-1}$ with a resolution of $2 \mathrm{~cm}^{-1}$. Spectra were obtained by signal averaging 32 successive scans. Every measurement was at least duplicated on two independent powder samples crushed by hand, with an agate pestle and mortar, and deposited on the ATR system. Spectra were normalized with respect to the $v_{4}$ band of the phosphate group at about $602 \mathrm{~cm}^{-1}$, according to a classical procedure $[83,84]$.

\subsubsection{NMR spectroscopy}

NMR spectra were recorded on a Bruker AVANCE 300 spectrometer: $\mathrm{B}_{0}=7.05 \mathrm{~T}$, $v_{0}\left({ }^{1} \mathrm{H}\right)=300.13 \mathrm{MHz}, v_{0}\left({ }^{31} \mathrm{P}\right)=121.49 \mathrm{MHz}, v_{0}\left({ }^{29} \mathrm{Si}\right)=59.62 \mathrm{MHz}$, using a CP-MAS Bruker probe with $4 \mathrm{~mm}$ rotors spinning at $14 \mathrm{kHz}$ for ${ }^{1} \mathrm{H}$ and ${ }^{31} \mathrm{P}$ and with $7 \mathrm{~mm}$ rotors spinning at 5 
$\mathrm{kHz}$ for ${ }^{29} \mathrm{Si}$. Chemical shifts are referenced to TMS for ${ }^{1} \mathrm{H}$ and ${ }^{29} \mathrm{Si}$ and $85 \%$ aqueous $\mathrm{H}_{3} \mathrm{PO}_{4}$

223 for ${ }^{31} \mathrm{P}$. Single pulse and CP (cross-polarization) MAS experiments have been used to study

224

225

226 these materials. CP MAS relies on the heteronuclear dipolar interaction between an abundant spin $\mathrm{X}\left({ }^{1} \mathrm{H}\right.$ here $)$ and a low abundant nuclei $\mathrm{Y}\left({ }^{31} \mathrm{P}\right.$ and ${ }^{29} \mathrm{Si}$ here $)$. It allows the study of local molecular motion. The NMR parameters are summarized in Table 2.

\subsubsection{Electron microscopy (HR-TEM, SAED and EDX)}

High resolution transmission electron microscopy (HR-TEM) was conducted on calcined powders $\left(1000^{\circ} \mathrm{C} / 15 \mathrm{~h}\right)$ using a JEOL $2010 \mathrm{~F}$ Microscope at a voltage of $200 \mathrm{kV}$. Samples were prepared by dispersing the powders in ethanol. After sonication at $40 \mathrm{~W}$ for $5 \mathrm{~min}$, a small drop of the suspension was placed onto copper mesh grids coated with a holey carbon film. Finally, a thin coating of gold (10 nm in thickness) was sputtered on half of the grid. Gold was then distributed as crystallized nano-domains which were used as a reference in the selected area electron diffraction (SAED) patterns to calculate as precisely as possible the lattice parameters. The SAED patterns obtained from regions with or without gold on the HA part were the same.

\subsubsection{Elemental analysis}

The silicon, phosphorous and calcium content in powders was determined by inductively coupled plasma atomic emission spectrometry (ICP/AES) (HORIBA Spectrometer, JobinYvon, Activa model). Powder samples were dissolved in a nitric acid solution (0.5 M). Solutions were prepared (e.g. powder mass, dilution) in order to limit the measurement uncertainty as well as to determine the concentrations of $\mathrm{Ca}, \mathrm{P}$ and $\mathrm{Si}$ within the highest sensitivity range of the ICP/AES device (around $30 \mathrm{ppm}$ ). Lastly, the carbon content in the powders was determined using an elemental analyzer with an infrared detector (LECO CS444 carbon and sulfur analyzer). 
247 powders containing $0 \leq \mathrm{wt} \% \mathrm{Si} \leq 2.81$ (or $0 \leq \mathrm{y} \leq 1.00$ ) are pure monophasic SiHAs

248

249

250

251

252

253

254

255

256

257

258

259

260

261

262

$\mathrm{Ca}_{10}\left(\mathrm{PO}_{4}\right)_{6-\mathrm{y}}\left(\mathrm{SiO}_{4}\right)_{\mathrm{y}}(\mathrm{OH})_{2-\mathrm{y}}\left(\mathrm{V}_{\mathrm{OH}}\right)_{\mathrm{y}}$, without any second crystalline or amorphous phase.

$\%$ wt Si $=\left(\mathrm{m}_{\mathrm{Si}} 100 / \mathrm{m}_{\text {SiyHA }}\right)=\left(\mathrm{Cm}_{\mathrm{Si}} \mathrm{V}_{\text {sol }} 100\right) /\left(\mathrm{m}_{\text {SiyHA }}\right)$

$\mathrm{n}_{\mathrm{Si}}=\left(\% \mathrm{wtSi} \mathrm{m}_{\text {SiyHA }}\right) /\left(\mathrm{M}_{\mathrm{Si}} 100\right)$

$\mathrm{M}_{\mathrm{SiyHA}}=\mathrm{M}_{\mathrm{HA}}-\left(19.895 \mathrm{y}_{\mathrm{Si}}\right)$

$\mathrm{y}_{\mathrm{Si}}=\left(\mathrm{n}_{\mathrm{Si}} \mathrm{M}_{\mathrm{SiyHA}}\right) /\left(\mathrm{m}_{\mathrm{SiyHA}}\right)=\left(\% \mathrm{wtSi} \mathrm{M}_{\mathrm{HA}}\right) /\left(100 \mathrm{M}_{\mathrm{Si}}+19.985 \% \mathrm{wt} \mathrm{Si}\right)$

where \%wt $\mathrm{Si}$ is the mass percentage of $\mathrm{Si}$ in the powder, $\mathrm{Cm}_{\mathrm{Si}}$ is the mass concentration of $\mathrm{Si}$ in the analyzed solution by ICP/AES (ppm or $\mathrm{mg} \mathrm{L}^{-1}$ ), $\mathrm{V}_{\text {sol }}$ is the volume of the analyzed solution (L), $\mathrm{m}_{\mathrm{SiyHA}}$ is the mass of the powder dissolved in the former solution (mg), and $\mathrm{M}_{\mathrm{SiyHA}}, \mathrm{M}_{\mathrm{HA}}$ and $\mathrm{M}_{\mathrm{Si}}$ are the molar masses of SiyHA, HA and Si, respectively $\left(\mathrm{g} \mathrm{mol}^{-1}\right)$.

\section{Results and discussion}

\subsection{Influence of pH on the SiHA phase composition}

$\mathrm{Si}_{0.50} \mathrm{HA}$ powders were synthesized at $50^{\circ} \mathrm{C}$ with $\mathrm{pH}$ values equal to $9.50\left(\mathrm{Si}_{0.50} \mathrm{HA}-9.5\right)$ and $10.80\left(\mathrm{Si}_{0.50} \mathrm{HA}-10.8\right)$. Fig. 1 shows the XRD diffractograms of powders calcined at $1000^{\circ} \mathrm{C}$ for $15 \mathrm{~h}$. The pattern of the $\mathrm{Si}_{0.50} \mathrm{HA}-9.5$ sample presents two different crystalline phases matching the ICDD standard for hydroxyapatite (HA, PDF 9-432) and $\alpha$-tricalcium phosphate ( $\alpha$-TCP, PDF 9-348). The $\mathrm{Si}_{0.50} \mathrm{HA}-10.8$ diffractogram displays only the characteristic diffraction lines of HA. This result indicates that the final composition of the powders is a function of silicate ion speciation. $\mathrm{H}_{3} \mathrm{SiO}_{4}{ }^{-}$or more basic forms of silicate ions have to be maintained during the synthesis to obtain a thermally stable SiHA phase, i.e. a monophasic powder after heat treatment at $1000^{\circ} \mathrm{C} / 15 \mathrm{~h}$. Therefore, herein, the following results are presented for powders prepared at $\mathrm{pH}$ 10.8. Under these synthesis conditions, the general reaction of precipitation can be written as follows:

$10 \mathrm{Ca}^{2+}+(6-\mathrm{y}) \mathrm{HPO}_{4}{ }^{2-}+\mathrm{yH}_{3} \mathrm{SiO}_{4}{ }^{-}+(8+\mathrm{y}) \mathrm{OH}^{-} \leftrightarrow \mathrm{Ca}_{10}\left(\mathrm{PO}_{4}\right)_{6-\mathrm{y}}\left(\mathrm{SiO}_{4}\right)_{\mathrm{y}}(\mathrm{OH})_{2-\mathrm{y}}\left(\mathrm{V}_{\mathrm{OH}}\right)_{\mathrm{y}}+(6+2 \mathrm{y}) \mathrm{H}_{2} \mathrm{O}$ 
271 To our knowledge, this is the first time that a true precipitation reaction has been given for 272 SiHA.

\section{$273 \quad 3.2$ Influence of the Si content $\left(\mathrm{y}_{\mathrm{Si}}\right)$}

274

\subsubsection{X-ray diffraction analysis}

Fig. 2 shows the diffraction patterns of $\mathrm{HA}$ and $\mathrm{Si}_{\mathrm{y}} \mathrm{HA}\left(\mathrm{y}_{\mathrm{Si}}=0.25,0.50,0.75,1.00\right.$ and 1.25 mol) raw powders. Each pattern matches well with the standard pattern of HA (PDF 9-432). No other phase was detected. The samples exhibit broad diffraction lines which indicate very small crystallites and/or low crystallinity. More, the FWHM increased with silicon content. The diffractograms of heat treated powders $\left(1000^{\circ} \mathrm{C} / 15 \mathrm{~h}\right)$ are displayed in Fig. 3. They present no secondary phase besides hydroxyapatite for a silicon content up to $\mathrm{y}_{\mathrm{Si}}=1.00$. On the other hand, HA (PDF 9-432) and $\alpha$-TCP (PDF 9-348) were detected in the pattern of $\mathrm{Si}_{1.25} \mathrm{HA}$ calcined at $1000^{\circ} \mathrm{C}$ for $15 \mathrm{~h}$. Moreover, as observed for the raw powders, the crystallinity of $\mathrm{Si}_{\mathrm{y}} \mathrm{HA}$ calcined powders with $1 \geq \mathrm{y} \geq 0$ decreased with an increase in the silicate content. Indeed, the higher the Si content, the higher the FWHM of the diffraction line. For instance, the FWHM of the diffraction line at $31.8^{\circ}(2 \theta)$ increased as follow: 0.070 $(\mathrm{HA})<0.096\left(\mathrm{Si}_{0.25} \mathrm{HA}\right)<0.160\left(\mathrm{Si}_{0.50} \mathrm{HA}\right)<0.164\left(\mathrm{Si}_{0.75} \mathrm{HA}\right)<0.170\left(\mathrm{Si}_{1.00} \mathrm{HA}\right)$. This is due to both direct (decrease in the crystallinity) and indirect (decrease in the crystallite size) effects of $\mathrm{Si}$, but the individual contributions of these effects cannot be evaluated by X-ray diffraction.

The XRD patterns indicate that whatever the amount of silicon ranging between $0 \leq$ $\mathrm{wt} \% \mathrm{Si} \leq 3.51$ (or $0 \leq \mathrm{y} \leq 1.25$ ), the crystalline phase of the precipitates is a hydroxyapatite (PDF 09-432). Thereby, silicon can be incorporated in the apatitic structure, or in an amorphous phase or in both phases. However, only precipitates containing up to $2.81 \mathrm{wt} \% \mathrm{Si}$ (or $\mathrm{y}=1.00$ ) are thermally stable at $1000^{\circ} \mathrm{C}$ for $15 \mathrm{~h}$.

\subsubsection{Lattice parameter refinement}


Refinement was performed on monophased heat-treated powders $(0 \leq \mathrm{y} \leq 1.00)$. The results,

297

298

299

300

301

302

303

304

305

306

307

308

309

310

311

312

313

314

315

316

317

displayed in Table 3, reveal changes in the apatitic structure parameters. The Si substitution causes $c$-axis and unit cell volume expansion as well as a reduction in the mean crystallite size. The same observation was reported in other studies [10, 17, 32, 70, 85]. On the other hand, and in contrast to the linear increase of the lattice parameter $c$ with an increasing amount of $\mathrm{Si}$, the $a$ lattice parameter fluctuates at random between $9.416 \AA$ and $9.428 \AA$. These results highlight that all or part of the silicon is incorporated into the apatitic structure.

\subsubsection{Elemental analysis}

The experimental $\mathrm{Ca} /(\mathrm{P}+\mathrm{Si})$ molar ratios of the final calcined powders are presented in Table 1. Values are in accordance with the expected ones (1.67) for all compositions, considering experimental error. Moreover, the calcined powders were not carbonated since the carbon content by weight was equal to $0.03,0.07,0.05,0.05$ and $0.05 \mathrm{wt} \%( \pm 0.02 \mathrm{wt} \%)$ for HA, $\mathrm{Si}_{0.25} \mathrm{HA}, \mathrm{Si}_{0.50} \mathrm{HA}, \mathrm{Si}_{0.75} \mathrm{HA}$ and $\mathrm{Si}_{1.00} \mathrm{HA}$, respectively.

The results, presented in Table 1, show that the chemical formulas of SiHA calculated first by the measured silicon contents, then by the the theoretical formula $\mathrm{Ca}_{10}\left(\mathrm{PO}_{4}\right)_{6}$ ${ }_{\mathrm{y}}\left(\mathrm{SiO}_{4}\right)_{\mathrm{y}}(\mathrm{OH})_{2-\mathrm{y}}\left(\mathrm{V}_{\mathrm{OH}}\right)_{\mathrm{y}}$ and finally using Eq. 4 are in a good agreement with the nominal ones.

\subsubsection{Electron microscopy}

A low magnification bright-field image of heat-treated $\mathrm{Si}_{1.00} \mathrm{HA}$ particles is shown in Fig. $4 \mathrm{a}$. SiHA powders are composed of round particles, smaller than $100 \mathrm{~nm}$ in diameter for $\mathrm{Si}_{1.00} \mathrm{HA}$, whereas the HA powder shows bigger acicular crystals [86]. At higher magnification, grains do not present any dislocation or disorder within the central region. Similarly, high-resolution lattice images of the grain surface do not show any amorphous or disordered layer (see Fig. 4b). A selected area electron diffraction (SAED) pattern obtained on the same grain is displayed in Fig. 5a. SAED patterns show a diffraction pattern with welldefined spots regardless of the selected area. This indicates the high crystallinity of the heat- 
treated SiHA powders and the homogeneity of the crystals. Second, a very good agreement appears between the SAED patterns and the PDF card 09-432 of HA as identified by X-ray diffraction. Moreover, no halo ring was observed, confirming the absence of the amorphous phase. Fig. 5b shows a SAED pattern for the [010] zone axis. Two other SAED patterns were obtained for the [1-10] zone axis. Indexation of these patterns allows for calculating the $c / a$ ratio by means of the interval between two spots. Thus, for instance, according to the hexagonal crystallographic structure identified by X-ray diffraction and the distance $\mathrm{D}_{1}$ and $\mathrm{D}_{2}$ between two spots along the [h00] and [001] directions ([010] zone axis, Fig. 5b), respectively, the $c / a$ ratio was calculated as follows:

$(c / a)^{2}=3 / 4\left(\mathrm{D}_{1} / \mathrm{D}_{2}\right)^{2}$

The results are the average of about ten intervals per pattern. A cla ratio of $0.730 \pm$ 0.005 was determined. Moreover, other experimental patterns for different zone axes (not shown here) were obtained and compared to theoretical electron diffraction patterns calculated by means of the Java Electron Microscopy Simulation (JEMS) software [87]. The results indicate that the experimental and simulated patterns are perfectly superimposed for $0.734 \geq \mathrm{c} / \mathrm{a} \geq 0.729$. Additionally, the c/a ratio value from PDF 09-432 (0.7309) is included in this range.

\subsubsection{Solid-state NMR analysis}

\subsubsection{1. ${ }^{31} \mathrm{P}$ MAS NMR}

The ${ }^{31} \mathrm{P}$ MAS NMR spectra of $\mathrm{HA}, \mathrm{Si}_{0.50} \mathrm{HA}$ and $\mathrm{Si}_{1.00} \mathrm{HA}$ calcined at $1000^{\circ} \mathrm{C}$ for $15 \mathrm{~h}$ are shown in Fig. 6a. The spectra present a main narrow peak which corresponds to the single $\mathrm{P}$ site of hydroxyapatite [88], and whose position shifts to higher frequencies with increasing silicon content: $2.8 \mathrm{ppm}$ for $\mathrm{HA}, 3.0 \mathrm{ppm}$ for $\mathrm{Si}_{0.50} \mathrm{HA}$, and $3.1 \mathrm{ppm}$ for $\mathrm{Si}_{1.00} \mathrm{HA}$. Likewise, the FWHM broadens: $166 \mathrm{~Hz}<188 \mathrm{~Hz}<233 \mathrm{~Hz}$ for raw HA, $\mathrm{Si}_{0.50} \mathrm{HA}$ and $\mathrm{Si}_{1.00} \mathrm{HA}$, respectively (figure not included), and $55 \mathrm{~Hz}<132 \mathrm{~Hz}<233 \mathrm{~Hz}$ for calcined $\mathrm{HA}, \mathrm{Si}_{0.50} \mathrm{HA}$ 
and $\mathrm{Si}_{1.00} \mathrm{HA}$, respectively (Fig. 6a). The chemical shift and peak broadening indicate that the SiHA structure is different from a perfect hydroxyapatite short-range structure. The increasing line width suggests an increase in local disorder around those phosphate groups where $\mathrm{Si}$ is incorporated in the HA structure. Besides the 2.8 ppm peak, two additional weak broad peaks at 4.6 and $5.8 \mathrm{ppm}$ were detected in the ${ }^{31} \mathrm{P}$ spectra. The peak at $4.6 \mathrm{ppm}$ was only revealed in the ${ }^{1} \mathrm{H} \rightarrow{ }^{31} \mathrm{P}$ CP MAS spectrum (Fig. 7b). HA powder did not present the $4.6 \mathrm{ppm}$ signal (Fig. 7a). According to Hartmann et al. [89], the ${ }^{31} \mathrm{P}$ MAS peak at $5.8 \mathrm{ppm}$ corresponds to $\mathrm{PO}_{4}$ tetrahedra in a proton-free region of a hydroxyapatite channel structure containing $\mathrm{OH}$ vacancies (i.e. along the crystallographic $c$-axis). These proton-free regions, observed in oxyhydroxyapatite $\mathrm{Ca}_{10}\left(\mathrm{PO}_{4}\right)_{6}(\mathrm{OH})_{2-2 \mathrm{x}}(\mathrm{O})_{\mathrm{x}}\left(\mathrm{V}_{\mathrm{OH}}\right)_{\mathrm{x}}(\mathrm{OHA})$, must exist in silicon-substituted hydroxyapatite $\quad \mathrm{Ca}_{10}\left(\mathrm{PO}_{4}\right)_{6-\mathrm{y}}\left(\mathrm{SiO}_{4}\right)_{\mathrm{y}}(\mathrm{OH})_{2-\mathrm{y}}\left(\mathrm{V}_{\mathrm{OH}}\right)_{\mathrm{y}} \quad(\mathrm{SiHA}), \quad$ or $\quad$ silicon-substituted oxyhydroxyapatite $\mathrm{Ca}_{10}\left(\mathrm{PO}_{4}\right)_{6-\mathrm{y}}\left(\mathrm{SiO}_{4}\right)_{\mathrm{y}}(\mathrm{OH})_{2-\mathrm{y}-2 \mathrm{x}} \mathrm{O}_{\mathrm{x}}\left(\mathrm{V}_{\mathrm{OH}}\right)_{\mathrm{x}+\mathrm{y}}(\mathrm{SiOHA})$. The assignment of the peak at $4.6 \mathrm{ppm}$, that seems related to the incorporation of $\mathrm{Si}$ in the apatite lattice, will be discussed later on (section 3.2.5.3).

\subsubsection{2. ${ }^{1}$ H MAS NMR}

The ${ }^{1} \mathrm{H}$ MAS NMR spectra of pure $\mathrm{HA}, \mathrm{Si}_{0.50} \mathrm{HA}$ and $\mathrm{Si}_{1.00} \mathrm{HA}$ powders calcined at $1000^{\circ} \mathrm{C}$ for $15 \mathrm{~h}$ are shown in Fig. 6b. Two signals were observed, one sharp at $0 \mathrm{ppm}$ and one broader at about $5.2 \mathrm{ppm}$. The former $(0 \mathrm{ppm})$ is characteristic of $\mathrm{OH}$ groups in crystalline HA [89]. Moreover, and similarly to the ${ }^{31} \mathrm{P}$ signal at $2.8 \mathrm{ppm}$, the greater the Si content in the apatitic structure of the calcined powders, the broader the FWHM of the signal at $0 \mathrm{ppm}$ $\left(\mathrm{FWHM}=108 \mathrm{~Hz}\right.$ for $\mathrm{HA}, 191 \mathrm{~Hz}$ for $\mathrm{Si}_{0.5} \mathrm{HA}$ and $228 \mathrm{~Hz}$ for $\mathrm{Si}_{1.00} \mathrm{HA}$ ). This suggests a change in the environment around the hydroxyl groups, highlighting the modification of $\mathrm{O}-\mathrm{H}$ bond distances due to Si. As postulated by Gomes et al., this concomitant broadening of the ${ }^{31} \mathrm{P}$ and ${ }^{1} \mathrm{H}$ resonances with $\mathrm{Si}$ content confirms the incorporation of $\mathrm{Si}$ atoms into the apatite lattice [30]. The signal at $5.2 \mathrm{ppm}$ was attributed by Hartmann et al. to $\mathrm{OH}^{-}$positions missing 
only one neighboring ion in OHA channels [89]. This type of $\mathrm{OH}^{-}$group along the channels of the apatite structure leads to the formation of "proton pairs" stabilized by a hydrogen bond. The intensity of this proton position is higher in SiHA samples than in HA, but does not seem to be an exclusive function of the Si content (see Fig. 6b). Therefore, ${ }^{1} \mathrm{H}$ MAS NMR indicates the presence of two types of $\mathrm{OH}^{-}$groups along the channels of the apatite structure: an unchanged proton line position with continuous $\mathrm{OH}^{-}$groups $(0 \mathrm{ppm})$ and $\mathrm{OH}^{-}$pairs surrounded by vacancies (5.2 ppm).

\subsubsection{3. ${ }^{1} \mathrm{H}^{31}{ }^{31} \mathrm{P}$ HETCOR CP MAS}

To confirm that the entire proton position is located in the apatite channel structure, twodimensional ${ }^{1} \mathrm{H}^{3}{ }^{31} \mathrm{P}$ HETCOR CP MAS experiments were performed on raw and calcined powders. Fig. 8 presents ${ }^{1} \mathrm{H}_{-}{ }^{31} \mathrm{P}$ HETCOR CP MAS spectra recorded on raw $\mathrm{Si}_{1.00} \mathrm{HA}$ (Fig. 8a) and calcined $\mathrm{Si}_{0.50} \mathrm{HA}$ (Fig. 8 b) powders. The spectra show two main $2 \mathrm{D}$ correlation peaks on both raw and calcined powders. The same peaks were observed for $\mathrm{Si}_{0.25} \mathrm{HA}, \mathrm{Si}_{0.50} \mathrm{HA}$ and $\mathrm{Si}_{1.00} \mathrm{HA}$ (HETCOR CP MAS results for calcined $\mathrm{Si}_{0.25} \mathrm{HA}$ and $\mathrm{Si}_{1.00} \mathrm{HA}$ not included). The stronger one (peak A, Fig. 8b), characteristic of an ideal HA structure, is due to the dipolar interaction between the $\mathrm{P}$ sites $\left(\delta\left({ }^{31} \mathrm{P}\right)=2.8 \mathrm{ppm}\right)$ and the $\mathrm{OH}$ sites $\left(\delta\left({ }^{1} \mathrm{H}\right)=0 \mathrm{ppm}\right)$. It corresponds to an undisturbed hydroxyapatite short-range structure [89]. The second one (peak B, Fig. 8b) appears between the ${ }^{31} \mathrm{P}$ signal at $4.6 \mathrm{ppm}$ and the ${ }^{1} \mathrm{H}$ signal at $5.2 \mathrm{ppm}$. Its intensity increases with heat treatment (Fig. 8) and the Si content (data not included). This correlation is not observed for the HA sample (data not included). Moreover, a low extent of peak B is observed with the main ${ }^{31} \mathrm{P}$ peak at $2.8 \mathrm{ppm}$ (peak C, Fig. 8b). The intensity of this 2D correlation peak becomes stronger with Si content as well. More generally, the higher the amount of $\mathrm{Si}$ incorporated into the SiHA structure, the stronger the dispersion of the main correlation between $\mathrm{A}$ and $\mathrm{B}$ along the ${ }^{31} \mathrm{P}$ axis. Finally, as expected, the HETCOR spectra show no correlation peak of the ${ }^{31} \mathrm{P}$ line at $5.8 \mathrm{ppm}$, confirming that it corresponds to a 
proton-free phosphate position. To conclude, first the broadening of peak A indicates an increase in the distribution of $\mathrm{P}-\mathrm{H}$ bond distances when silicate is incorporated into the HA structure, corresponding to the loss of local ordering in the phosphate environment. Second, peaks $\mathrm{B}$ and $\mathrm{C}$ correspond to two distinct $\mathrm{P}$ sites in the vicinity of isolated pairs of protons $\left(\mathrm{OH}^{-}\right.$pairs $)$present in the channel structure of silicon-substituted oxyhydroxyapatite $\mathrm{Ca}_{10}\left(\mathrm{PO}_{4}\right)_{6-\mathrm{y}}\left(\mathrm{SiO}_{4}\right)_{\mathrm{y}}(\mathrm{OH})_{2-\mathrm{y}-2 \mathrm{x}} \mathrm{O}_{\mathrm{x}}\left(\mathrm{V}_{\mathrm{OH}}\right)_{\mathrm{y}+\mathrm{x}}(\mathrm{SiOHA})$ : (i) peak $\mathrm{B}$ represents a very strongly distorted hydroxyapatite short-range structure and (ii) peak $\mathrm{C}$ represents a less distorted one. Peak $\mathrm{B}$ is clearly related to $\mathrm{SiO}_{4}$ substitution and proves once again that charge compensation implies $\mathrm{OH}$ vacancies along the channels, leading to the formation of $\mathrm{OH}^{-}$pairs in the vicinity of the substituted $\mathrm{PO}_{4}$ tetrahedra. Peak $\mathrm{C}$ can be due to $\mathrm{SiO}_{4}$ substitution as well as dehydration of SiHA, both leading to the formation of $\mathrm{OH}$ vacancies in SiOHA.

\subsubsection{4. ${ }^{29} \mathrm{Si}$ MAS NMR}

The ${ }^{29} \mathrm{Si}$ MAS NMR spectra of $\mathrm{Si}_{1.00} \mathrm{HA}$ powders, raw and calcined, are shown in Fig. 9. The raw powders present two resonances: one sharp at about $-72 \mathrm{ppm}$ that is clearly attributed to $\mathrm{SiO}_{4}{ }^{4-}\left(\mathrm{Q}^{0}\right)$ in the apatitic structure [90], and a broad peak at about -100/-110 ppm which corresponds to $\mathrm{Q}^{3} / \mathrm{Q}^{4}$ silicon species [16]. The results confirm that the main part of the silicate is incorporated into the HA lattice during precipitation, according to the main reaction Eq. 1. The rest of the silicates are adsorbed at the crystallite surface, as observed for phosphates during the precipitation of apatitic calcium phosphates [91, 92]. After calcination, the broad peak at $-100 /-110$ ppm disappears without the detection of new signals, similar to those reported in the literature $\left(\mathrm{Si}-\mathrm{TCP}\right.$ or $\left.\alpha-\mathrm{Ca}_{3} \mathrm{Si}_{3} \mathrm{O}_{9}\right)[16,30,38]$. The same results were obtained for the $\mathrm{Si}_{0.25} \mathrm{HA}$ and $\mathrm{Si}_{0.50} \mathrm{HA}$ samples (data not included).

\subsubsection{FT-IR analysis}

\subsubsection{As-synthesized samples}


The IR spectra of the raw HA and SiHA powders with a silicon content up to $\mathrm{y}_{\mathrm{Si}}=1.25 \mathrm{~mol}$ (figure not included) present strong similarities and exhibit intense bands characteristic of hydroxyapatite. They correspond to the four vibrational modes of phosphate groups $\left(v_{1}, v_{2}, v_{3}\right.$, and $\left.v_{4}\right)$, and the stretching $\left(v_{S}\right)$ and librational $\left(v_{L}\right)$ modes of the hydroxide groups [81, 92-94]. The intensity of the latter, at $630 \mathrm{~cm}^{-1}\left(v_{\mathrm{L}}\right)$ and $3570 \mathrm{~cm}^{-1}\left(v_{\mathrm{S}}\right)$, clearly decreased with the amount of silicon. These results confirm that the as-synthesized precipitates exhibit the hydroxyapatite phase, regardless of the amount of silicon ranging between $0 \leq \mathrm{wt} \% \mathrm{Si} \leq \_3.51$ (or $0 \leq \mathrm{y} \leq 1.25$ ), as observed on the diffractograms (Fig. 2). A more accurate description of the infrared spectra of the as-synthesized SiHA powders is available in a complementary article [95].

\subsubsection{Calcined samples - general observations}

Fig. 10 compares the infrared spectra of heat-treated HA and SiHA powders $\left(1000^{\circ} \mathrm{C} / 15 \mathrm{~h}\right)$. The HA and $\mathrm{Si}_{\mathrm{y}} \mathrm{HA}$ with $0 \leq \mathrm{y} \leq 1.0$ powders mainly present bands characteristic of hydroxyapatite with the $v_{1}\left(962 \mathrm{~cm}^{-1}\right), v_{2}\left(473 \mathrm{~cm}^{-1}\right), v_{3}\left(1021\right.$ and $\left.1085 \mathrm{~cm}^{-1}\right)$ and $v_{4}(562$ and $\left.600 \mathrm{~cm}^{-1}\right)$ modes of $\mathrm{PO}_{4}{ }^{3-}$, as well as the stretching $\left(v_{\mathrm{S}}: 3572 \mathrm{~cm}^{-1}\right)$ and librational $\left(v_{\mathrm{L}}: 629 \mathrm{~cm}^{-}\right.$ ${ }^{1}$ ) modes of hydroxide groups [81, 92, 94]. A shoulder at $947 \mathrm{~cm}^{-1}$ was also observed for HA and SiHA powders. The relative intensity of this shoulder was slightly higher for SiHA than for HA, but did not seem to be a function of the amount of Si. Besides the low hydroxyapatite vibrations, the spectrum of the $\mathrm{Si}_{1.25} \mathrm{HA}$ powder presents mainly the characteristic bands of $\alpha$ TCP and traces of $\beta$-tricalcium phosphates ( $\beta$-TCP): the weak band at $495 \mathrm{~cm}^{-1}$ ascribed to the O-P-O $v_{2}$ vibrational mode of $\beta$-TCP, the bands due to the splitting of the $v_{4}$ mode at 567 $\mathrm{cm}^{-1}$ in $\alpha$-TCP $\left(551,560,580,595\right.$ and $\left.611 \mathrm{~cm}^{-1}\right)$, the bands at 945 and $955 \mathrm{~cm}^{-1}$ assigned to the degenerated symmetric P-O stretching vibration of the phosphate ions $\left(v_{1}\right)$ in $\beta$ - and $\alpha-$ TCP, respectively, and the bands corresponding to the strong asymmetric P-O stretching mode $\left(v_{3}\right)$ for $\beta$-TCP $\left(988,1025 \mathrm{~cm}^{-1}\right)$ and $\alpha$-TCP $\left(988,1013,1025,1031\right.$ and $\left.1055 \mathrm{~cm}^{-1}\right)$ [52, 
96]. This result is complementary to the X-ray diffraction pattern (Fig. 3) and indicates that the $\mathrm{Si}_{1.25} \mathrm{HA}$ apatitic precipitate decomposes during heat treatment with the formation of TCP and amorphous silica species.

\subsubsection{Calcined samples - accurate IR band assignment of the pure SiHA phase}

As opposed to HA, the FT-IR spectra of the calcined $\mathrm{Si}_{\mathrm{y}} \mathrm{HA}$ powders, with $0 \leq \mathrm{y} \leq 0.75$, exhibit nine new bands or shoulders (sh) at 491 (sh), 504, 528, 750, 840, 893, 930 (sh), 985 (sh) and $1002(\mathrm{sh}) \mathrm{cm}^{-1}$. The intensity of these new vibrations increased with the amount of $\mathrm{Si}$, except for the weak band at $840 \mathrm{~cm}^{-1}$ and the shoulder at $930 \mathrm{~cm}^{-1}$ which remained relatively constant. Conversely, the intensity of the absorption bands attributed to the four vibrational modes of $\mathrm{PO}_{4}{ }^{3-}$ and both modes of $\mathrm{OH}^{-}$in hydroxyapatite decreased as the amount of $\mathrm{Si}$ increased in the range $0 \leq \mathrm{y} \leq 1.00\left(\right.$ e.g. $v_{\mathrm{S}} \mathrm{OH}: 0.49(\mathrm{HA})>0.39\left(\mathrm{Si}_{0.25} \mathrm{HA}\right)>0.35$ $\left.\left(\mathrm{Si}_{0.50} \mathrm{HA}\right)>0.12\left(\mathrm{Si}_{0.75} \mathrm{HA}\right)>0.07\left(\mathrm{Si}_{1.00} \mathrm{HA}\right)\right)$. More precisely, the $v_{\mathrm{L}}$ mode decreased to the detection limit for $\mathrm{y}=1$, while the stretching the $\mathrm{OH}^{-}$band decreased and broadened. In fact, two new vibrations at 3565 and $3552 \mathrm{~cm}^{-1}$, close to the main one at $3572 \mathrm{~cm}^{-1}$, were detected (Fig. 10). This confirms the mechanism of charge compensation with the creation of $\mathrm{OH}^{-}$ vacancies, and highlights the new environment and distribution of $\mathrm{OH}^{-}$ions along the channels of the SiHA structure $[93,97]$ and, more importantly, the formation of low hydrogen bonding between closed $\mathrm{O}^{2-}$ and $\mathrm{OH}^{-}$ions (H-bonds cause a shift of $20 \mathrm{~cm}^{-1}$ to the low wavenumber of the main band at $3572 \mathrm{~cm}^{-1}$ [98]). The FT-IR spectrum of $\mathrm{Si}_{1.0} \mathrm{HA}$ displays the same eight new bands as those detected on $\mathrm{Si}_{0.25} \mathrm{HA}, \mathrm{Si}_{0.50} \mathrm{HA}$ and $\mathrm{Si}_{0.75} \mathrm{HA}$. However, their relative intensity decreased significantly, reaching the detection limit for the band at 750 $\mathrm{cm}^{-1}$ and with a complete disappearance of the bands at 491, 504, and $528 \mathrm{~cm}^{-1}$. Additionally, seven new vibrations appeared at 500, 515, 535, 683, 798 and $873 \mathrm{~cm}^{-1}$. They were accompanied by an intensification of the shoulder at $947 \mathrm{~cm}^{-1}$. The bands at 683,798 and 870 $\mathrm{cm}^{-1}$ were also detected in spectrum of $\mathrm{Si}_{1.25} \mathrm{HA}$ calcined powder. According to these results 
and an accurate review of the bibliography, summarized in Table 4 , it is clear that the nine vibrations at $493,504,528,750,840,893,930,985$ and $1002 \mathrm{~cm}^{-1}$ are related to the incorporation of $\mathrm{Si}$ into the hydroxyapatite structure. The changes detected in the sample $\mathrm{Si}_{1.0} \mathrm{HA}$ were due to the start of decomposition of the SiHA phase, emphasized by a decrease in the nine characteristic bands and the formation of an amorphous silica phase which presents vibrations at 500,515, 535, 683, 798 and $873 \mathrm{~cm}^{-1}$. Silica was not detected by NMR due to the low amount of ${ }^{29} \mathrm{Si}$ in the samples (high detection limit). The shoulder at $947 \mathrm{~cm}^{-1}$ could be attributed to $\beta$-TCP, which exhibits a symmetric $\mathrm{P}-\mathrm{O}$ stretching mode $v_{1}$ at $945 \mathrm{~cm}^{-1}$ [96]. However, this assumption is not convincing since other bands assigned to $\beta$-TCP are absent. In fact, this shoulder is a contribution of the $\mathrm{Si}-\mathrm{O}$ in plane stretching vibrations in $\mathrm{Si}$ $\mathrm{OH}$ and $\mathrm{Si}^{-} \mathrm{O}^{-}$on the surface of the grains, and the symmetric stretching $\left(v_{1}\right)$ vibration of orthophosphate groups in the neighborhood of $\mathrm{OH}$ vacancies along the channels. The former, reported at $950 \mathrm{~cm}^{-1}$ (see Table 4), shifted toward lower frequencies due to hydrogen bonding between surface groups, thus creating the component at $930 \mathrm{~cm}^{-1}$. The band at $950 \mathrm{~cm}^{-1}$ is commonly observed for oxy-hydroxyapatite $\mathrm{Ca}_{10}\left(\mathrm{PO}_{4}\right)_{6}(\mathrm{OH})_{2-2 \mathrm{x}} \mathrm{O}_{\mathrm{x}}\left(\mathrm{V}_{\mathrm{OH}}\right)_{\mathrm{x}}$, [93, 99-102]. Therefore, in the context of this study, $\mathrm{OH}^{-}$vacancies $\left(\mathrm{V}_{\mathrm{OH}}\right)$ are due first to the incorporation of $\mathrm{SiO}_{4}$ into the HA structure, and second to the partial dehydration of $\mathrm{SiHA}$ to SiOHA as follows:

$\mathrm{Ca}_{10}\left(\mathrm{PO}_{4}\right)_{6-\mathrm{y}}\left(\mathrm{SiO}_{4}\right)_{\mathrm{y}}(\mathrm{OH})_{2-\mathrm{y}}\left(\mathrm{V}_{\mathrm{OH}}\right)_{\mathrm{y}} \leftrightarrow \mathrm{Ca}_{10}\left(\mathrm{PO}_{4}\right)_{6-\mathrm{y}}\left(\mathrm{SiO}_{4}\right)_{\mathrm{y}}(\mathrm{OH})_{2-\mathrm{y}-2 \mathrm{x}} \mathrm{O}_{\mathrm{x}}\left(\mathrm{V}_{\mathrm{OH}}\right)_{\mathrm{y}+\mathrm{x}}+\mathrm{x} \mathrm{H} \mathrm{H}_{2} \mathrm{O}$

\subsubsection{Calcined samples - OH vacancies and the limit of incorporation of $\mathrm{Si}$ in $\mathrm{HA}$}

The amount of hydroxide $(\% \mathrm{OH})$ in the silicon-substituted hydroxyapatite structure is reported versus the amount of silicon $\left(\mathrm{mol} \mathrm{mol}_{\mathrm{SiHA}}{ }^{-1}\right)$ in Fig. 11. The theoretical values of $\mathrm{OH}$ were plotted by considering the formula $\mathrm{Ca}_{10}\left(\mathrm{PO}_{4}\right)_{6-\mathrm{y}}\left(\mathrm{SiO}_{4}\right)_{\mathrm{y}}(\mathrm{OH})_{2-\mathrm{y}}\left(\mathrm{V}_{\mathrm{OH}}\right)_{\mathrm{y}}($ i.e. $\% \mathrm{OH}=100$ 50 y). The experimental values were determined at room temperature on the calcined samples $\left(1000^{\circ} \mathrm{C} / 15 \mathrm{~h}\right)$ by means of the integrated area of the $v_{\mathrm{L}}$ and $v_{\mathrm{S}} \mathrm{OH}$ bands. The average of the 
integrated areas obtained for HA $(\mathrm{y}=0)$ was assumed to be representative of the full occupancy of the $\mathrm{OH}$ position within the channels $(100 \% \mathrm{OH})$. The amount of $\mathrm{OH}$ vacancies $\left(\mathrm{V}_{\mathrm{OH}}\right)$ determined experimentally was always higher than the theoretical one with respect to the chemical formula $\mathrm{Ca}_{10}\left(\mathrm{PO}_{4}\right)_{6-\mathrm{y}}\left(\mathrm{SiO}_{4}\right)_{\mathrm{y}}(\mathrm{OH})_{2-\mathrm{y}}\left(\mathrm{V}_{\mathrm{OH}}\right)_{\mathrm{y}}$. In other words, the dehydration of the calcined powders was greater than expected, and a higher Si doping level led to a greater difference. Thus, the incorporation of $\mathrm{Si}$ into the hydroxyapatite structure generates $\mathrm{OH}$ vacancies first to maintain the charge balance $\left(\mathrm{Ca}_{10}\left(\mathrm{PO}_{4}\right)_{6-\mathrm{y}}\left(\mathrm{SiO}_{4}\right)_{\mathrm{y}}(\mathrm{OH})_{2-\mathrm{y}}\left(\mathrm{V}_{\mathrm{OH}}\right)_{\mathrm{y}}\right)$ and second from another phenomena, which is an increasing function of the amount of Si. A possible explanation is an increase of the mobility of $\mathrm{OH}$ ions along the channel axis (local disorder) and their subsequent rate of diffusion and debonding from the HA lattice [103]. HA decomposition is a dynamic process, mainly controlled by the degree of dehydration [104106]. In fact, the thermal stability of hydroxyapatite was found to depend on the fraction of $\mathrm{V}_{\mathrm{OH}}$ and $\mathrm{O}^{2-}$ ions in the channels. Several "critical values" of $\mathrm{V}_{\mathrm{OH}}$ in $\mathrm{OHA} \mathrm{Ca} \mathrm{Ca}_{10}\left(\mathrm{PO}_{4}\right)_{6}(\mathrm{OH})_{2-}$ ${ }_{2 \mathrm{x}} \mathrm{O}_{\mathrm{x}}\left(\mathrm{V}_{\mathrm{OH}}\right)_{\mathrm{x}}$ have been reported beyond which the apatite channel structure is destroyed: $\mathrm{x} \leq$ 0.80 [103], $\mathrm{x} \leq 0.75$ [107], $\mathrm{x} \leq 0.50$ [89]. However, the most probable limit comes from work of Heughebaert and Montel on the crystallization of calcium phosphates during precipitation $[108,109]$. They determined that the apatitic structure appears only when at least $25 \%$ of the $\mathrm{OH}^{-}$positions along the channels are really occupied. In other words, the apatitic structure appears when $\mathrm{V}_{\mathrm{OH}}<1.5$. Therefore, the theoretical maximum limit of incorporation of Si into a hexagonal apatitic structure is $\mathrm{y}<1.5$ as regards the formula $\mathrm{Ca}_{10}\left(\mathrm{PO}_{4}\right)_{6-\mathrm{y}}\left(\mathrm{SiO}_{4}\right)_{\mathrm{y}}(\mathrm{OH})_{2-}$ $\mathrm{y}\left(\mathrm{V}_{\mathrm{OH}}\right)_{\mathrm{y}}$. However, due to the dehydration reaction (Eq. 7), this limit is a function of the temperature and the atmosphere of heat treatment. This assumption can explain why the $\mathrm{Si}_{1.0} \mathrm{HA}$ and $\mathrm{Si}_{1.25} \mathrm{HA}$ powders, which showed an apatitic structure after calcination at $400^{\circ} \mathrm{C}$ for $2 \mathrm{~h}$, were not thermically stable at $1000^{\circ} \mathrm{C}$ for $15 \mathrm{~h}$ in contrast to SiHA with a silicon content ranging between $0 \leq \mathrm{y} \leq 0.75$. Control of the degree of hydroxylation, i.e. the partial 
steam pressure $\mathrm{p}_{\mathrm{H} 20}$, is necessary to control the thermal stability of the SiHA phase. This assumption is confirmed by the infrared spectra obtained from the $\mathrm{Si}_{1.0} \mathrm{HA}$ sample heat treated at $1000^{\circ} \mathrm{C}$ for $15 \mathrm{~h}$ under different partial pressures of steam, $\mathrm{p}_{\mathrm{H} 20}$, in mbar (Fig. 12); a higher $\mathrm{p}_{\mathrm{H} 20}$ led to a more stable silicon-substituted apatite phase. Thus, the $\mathrm{Si}_{1.0} \mathrm{HA}$ powder, after calcination under high steam pressure $\left(\mathrm{p}_{\mathrm{H} 20}=200\right.$ mbar $)$, presented only the characteristic bands of SiHA with traces of amorphous silica at the IR spectroscopy detection limit $(\approx 0.1 \mathrm{wt} \%)$, whereas the same sample heat-treated under dry argon gas $\left(\mathrm{pH}_{2} \mathrm{O}=0\right.$ mbar $)$ contained amorphous silica species as well as TCP ( $\alpha$ and $\beta)$. Moreover, the vibrations related to $\mathrm{Si}-\mathrm{O}$ in $\mathrm{SiHA}\left(750\right.$ and $\left.890 \mathrm{~cm}^{-1}\right)$ as well as the vibrational modes $v_{3}$ and $v_{4}$ of the phosphate groups in HA decreased with a decrease in $\mathrm{p}_{\mathrm{H} 20}$. Conversely, the vibrations due to amorphous silica species, at 683, 798 and $873 \mathrm{~cm}^{-1}$, and TCP (e.g. 731, 942, 997 and $1137 \mathrm{~cm}^{-1}$ ) increases with a decrease in $\mathrm{p}_{\mathrm{H} 20}$.

These results confirm that the formation of amorphous silica and the decomposition of the SiHA phase are correlated. More precisely, the detection of amorphous silica indicates the start of decomposition, which is followed by the formation of TCP ( $\alpha$ and $\beta)$.

Finally, Trombe and Montel reported the variation of $a$ from $9.421 \AA$ to $9.402 \AA$, without a significant variation in the $c$ lattice parameter, when HA transforms into OHA, $\mathrm{Ca}_{10}\left(\mathrm{PO}_{4}\right)_{6}(\mathrm{OH})_{0.5} \mathrm{O}_{0.75}\left(\mathrm{~V}_{\mathrm{OH}}\right)_{0.75}$ [102]. Thus, SiHA dehydration can explain the random fluctuations in the $a$ lattice parameter observed in this work and in the literature [30].

\section{Conclusion}

This paper presents a new route to synthesize monophasic silicon-containing hydroxyapatites $\mathrm{Ca}_{10}\left(\mathrm{PO}_{4}\right)_{6-\mathrm{y}}\left(\mathrm{SiO}_{4}\right)_{\mathrm{y}}(\mathrm{OH})_{2-\mathrm{y}}\left(\mathrm{V}_{\mathrm{OH}}\right)_{\mathrm{y}}(\mathrm{SiHAs})$ with controlled stoichiometry. The combination of solid state nuclear magnetic resonance (NMR) and IR spectroscopy (IR) demonstrated that silicate substitution for phosphate creates $\mathrm{OH}$ vacancies along the channels. Moreover, $\mathrm{Si}$ substitution increases the local disorder and the mobility of $\mathrm{OH}$ ions along these channels and 
545 their subsequent rate of diffusion and debonding from the HA lattice. The control of the 546 degree of hydroxylation of the SiHA phases, i.e. their thermal stability, can be carried out by

547 means of the partial steam pressure, $\mathrm{p}_{\mathrm{H} 20}$. Additionally, an exhaustive description of the 548 infrared bands related to the incorporation of silicate groups into the HA structure was 549 established. It allowed us to determine that the literature has incorrectly attributed some 550 infrared bands to silicate groups in the apatite structure. These bands, e.g. 683, 798 and 873 $551 \mathrm{~cm}^{-1}$, due in fact to amorphous silica phases, raise questions regarding the phase purity of the 552 great majority of biologically evaluated SiHA bioceramics.

553

554

555 Acknowledgments

556 The authors wish to thank the "Region Rhône-Alpes" for the financial support provided for 557 this work. 


\section{References}

[1] Carlisle EM. Silicon: A Possible Factor in Bone Calcification. Science 1970;167:279-80.

[2] Carlisle EM. In vivo requirement for silicon in articular cartilage and connective tissue formation in the chick. The journal of nutrition 1976;106:478-84.

[3] Nielsen FH, Poellot R. Dietary silicon affect bone turnover differently in ovariectomized and sham-operated growing rats. The journal of the trace elements in experimental medecine 2004;17:137-49.

[4] Schwarz K, Milne D. Growth promoting effects of silicon in rats. Nature 1972;239 333-4.

[5] Damen JJM, M. TCJ. Silica-induced Precipitation of Calcium Phosphate in the Presence of Inhibitors of Hydroxyapatite Formation. Journal of dental Research 1992;71:453-7.

[6] Jugdaohsingh R. Silicon and bone health. The Journal of Nutrition Health and Aging 2007;11:99-110.

[7] Reffitt DM, Ogston N, Jugdaohsingh R, Cheung HFJ, Evans BAJ, Thompson RPH, et al. Orthosilicic acid stimulates collagen type 1 synthesis and osteoblastic differentiation in human osteoblast-like cells in vitro. Bone 2003;32:127-35.

[8] Gibson IR, Best SM, Bonfield W. Chemical characterization of silicon-substituted hydroxyapatite. J Biom Mat Res 1999;44:422-8.

[9] Patel N, Best SM, Bonfield W, Gibson IR, Hing KA, Damien E, et al. A comparative study on the in vivo behavior of hydroxyapatite and silicon substituted hydroxyapatite granules. J MatSci: Materials in Medicine 2002;13:1199-206.

[10] Arcos D, Rodríguez-Carvajal J, Vallet-Regí M. The effect of the silicon incorporation on the hydroxylapatite structure. A neutron diffraction study. Solid State Sciences 2004;6:98794.

[11] Astala R, Calderin L, Yin X, Stott MJ. Ab Initio Simulation of Si-Doped Hydroxyapatite. Chem Mat 2006;18:413-22.

[12] Gibson IR, Huang J, Best SM, Bonfield W. Enhanced in vitro cell activity and surface apatite layer formation on novel silicon-substituted hydroxyapatites. Bioceramics 1999;12:191-4.

[13] Best S, Bonfield W, R. Gi, Jha LJ, Da Silva Santos JD. Silicon-substituted apatites and process for the preparation thereof. United States Patent, US 6,312,468 B1

Great Britain, London1998.

[14] Thian ES, Huang J, Vickers ME, Best SM, Barber ZH, Bonfield W. Silicon-substituted hydroxyapatite (SiHA): A novel calcium phosphate coating for biomedical applications. Journal of Materials science 2006;41:709-17.

[15] Vallet-Regí M, Arcos D. Silicon substituted hydroxyapatites. A method to upgrade calcium phosphate based implants. Journal of Materials chemistry 2005;15.

[16] Gasquères G, Bonhomme C, Maquet J, Babonneau F, Hayakawa S, Kanaya T, et al. Revisiting silicate substituted hydroxyapatite by solid-state NMR. Magn Reson Chem 2008;46:342-6.

[17] Tang XL, Xiao XF, Liu RF. Structural characterization of silicon-substituted hydroxyapatite synthesized by a hydrothermal method. Materials Letters 2005;59:3841-6. 
[18] Gomes S, Nedelec J-M, Jallot E, Sheptyakov D, Renaudin G. Silicon location in silicatesubstituted caclium phosphate ceramics determined by neutron diffraction. Crystal growth and design 2011;11:4017-26.

[19] Kim SR, Lee JH, Kim YT, Riu DH, Jung SJ, Lee YJ, et al. Synthesis of Si, Mg substituted hydroxyapatites and their sintering behaviors. Biomaterials 2003;24:1389-98.

[20] Ruys AJ. Silicon-doped hydroxyapatite. Journal of the Australian ceramic society 1993;29:71-80.

[21] Putlayev V, Veresov A, Pulkin M, Soin A, Kuznetsov V. Silicon-substituted hydroxyapatite ceramics (Si-HAP): densification and grain growth through the prism of sintering theories. Materials Science and Engineering Technology 2006;37:416-21.

[22] Best SM, Zou S, Brooks RA, Huang J, Rushton N, Bonfield W. The osteogenic behaviour of silicon substituted hydroxyapatite. Key Engineering Materials 2008;361363:985-8.

[23] Hing KA, Revell PA, Smith N, Buckland T. Effect of silicon level on rate, quality and progression of bone healing within silicate-substituted porous hydroxyapatite scaffolds. Biomaterials 2006;27:5014-26.

[24] Bothelo CM, Brooks RA, Best SM, Lopes MA, Santos JD, Rushton N, et al. Human osteoblast response to silicon-substituted hydroxyapatite. Journal of Biomedical Materials Research 2006;79A:723-30.

[25] Thian ES, Huang J, Best SM, Barber ZH, Brooks RA, Rushton N, et al. The response of osteoblasts to nanocrystalline silicon-substituted hydroxyapatite thin films. Biomaterials 2006;27:2692-8.

[26] Hing KA, Wilson LF, Buckland T. Comparative performance of three ceramic bone graft substitutes. The Spine Journal 2007;7:475-90.

[27] Palard M, Combes J, Champion E, Foucaud S, Rattner A, Bernache-Assollant D. Effect of silicon content on the sintering and biological behaviour of $\mathrm{Ca}_{10}\left(\mathrm{PO}_{4}\right)_{6-\mathrm{x}}\left(\mathrm{SiO}_{4}\right)_{\mathrm{x}}(\mathrm{OH})_{2-\mathrm{x}}$ ceramics. Acta Biomaterialia 2009;5:1223-32.

[28] Boanini E, Gazzano M, Bigi A. Ionic substitutions in calcium phosphates synthesized at low temperature. Acta Biomaterialia 2010;6:1882-94.

[29] Bohner M. Silicon-substituted calcium phosphates - A critical view. Biomaterials 2009;30:6403-6.

[30] Gomes S, Renaudin G, Mesbah A, Jallot E, Bonhomme C, Babonneau F, et al. Thorough analysis of silicon substitution in biphasic calcium phosphate bioceramics: A multi-technique study. Acta Biomaterialia 2010;6:3264-74.

[31] Langstaff S, Sayer M, Smith TJN, Pugh SM. Resorbable bioceramics based on stabilized calcium phosphates. Part II: evaluation of biological response. Biomaterials 2001;22:135-50.

[32] Palard M, Champion E, Foucaud S. Synthesis of silicated hydroxyapatite $\mathrm{Ca}_{10}\left(\mathrm{PO}_{4}\right)_{6-\mathrm{x}}\left(\mathrm{SiO}_{4}\right)_{\mathrm{x}}(\mathrm{OH})_{2-\mathrm{x}}$. Journal of Solid State Chemistry 2008;181:1950-60.

[33] Pietak AM, Reid JW, Sayer M. Electron spin resonance in silicon substituted apatite and tricalcium phosphate. Biomaterials 2005;26:3819-30.

[34] Reid JW, Tuck L, Sayer M, Fargo K, Hendry JA. Synthesis and characterization of single-phase silicon-substituted $\alpha$-tricalcium phosphate. Biomaterials 2006;27:2916-25. 
[35] Tang Q, Brooks RA, Rushton N. Production and characterization of HA and SiHA coatings. Journal of Materials Science: Materials in Medicine 2010;21:173-81.

[36] Arcos D, Rodríguez-Carvajal J, Vallet-Regí M. Silicon incorporation in hydroxyapatite obtained by controlled crystallization. Chemistry of materials 2004;16:2300-8.

[37] Balas F, Pérez-Pariente J, Vallet-Regí M. In vitro bioactivity of silicon-substituted hydroxyapatites. Journal of Biomedical Materials Research Part A 2003;66A:364-75.

[38] Kanaya T, Tsuru K, Hayakawa S, Osaka A, Fujii E, Kowabata K, et al. Structure and in vitro solubility of silicon-substituted hydroxyapatite. Key Engineering Materials 2008;361363:63-6.

[39] Botelho CM, Lopes MA, Gibson IR, Best SM, Santos JD. Structural analysis of Sisubstituted hydroxyapatite: zeta potential and X-ray photoelectroscopy. J Mat Sc 2002;13:1123-7.

[40] Bothelo CM, Brooks RA, Best SM, Lopes MA, Santos JD, Rushton N, et al. Biological and physical-chemical characterization of phase pure HA and Si-Substituted Hydroxyapatite by different microscopy techniques. Key Engineering Materials 2004;254-256:845-8.

[41] Bothelo CM, Brooks RA, Kawai T, Ogata S, Ohtsuki C, Best SM, et al. In vitro analysis of protein adhesion to phase pure hydroxyapatite and silicon substituted hydroxyapatite. Key Engineering Materials 2005;284-286:461-4.

[42] Bothelo CM, Brooks RA, Spence G, I. M, Lopes MA, Best SM, et al. Differenciation of mononuclear precursors into osteoclasts on the surface of Si-Substituted hydroxyapatite. Journal of biomedical Materials research part A 2006;78A:709-20.

[43] Bothelo CM, Stokes DJ, Brooks RA, Best SM, Lopes MA, Santos JD, et al. Effect of the human serum proteins on pure hydroxyapatite and silicon substituted hydroxyapatite: AFM and SEM studies. Materials Science Forum 2004;455-456:378-82.

[44] Gibson IR, Best SM, Bonfield W. Effect of Silicon substitution on the sintering and microstructure of hydroxyapatite. Journal of the American Ceramic Society 2002;85:2771-7.

[45] Gupta G, Kirakodu S, El-Ghannam A. Dissolution kinetics of a Si-rich nanocomposite and its effect on osteoblast gene expression. Journal of Biomedical Materials Research 2006;80A:486-96.

[46] Guth K, Campion C, Buckland T, Hing KA. Effect of Silicate-Substitution on Attachment and Early Development of Human Osteoblast-Like Cells Seeded on Microporous Hydroxyapatite Discs. Advanced Engineering Materials 2010;12:1527-2648.

[47] Guth K, Campion C, Buckland T, Hing KA. Effects of serum protein on ionic exchange between culture medium and microporous hydroxyapatite and silicate-substituted hydroxyapatite. Journal of Materials Science: Materials in Medicine 2011;22:2155-64.

[48] Hijón N, Victoria Cabañas M, Peña J, Vallet-Regí M. Dip coated silicon-substituted hydroxyapatite films. Acta Biomaterialia 2006;2:567-74.

[49] Lehmann G, Palmero P, Cacciotti I, Pecci R, Campagnolo L, Bedini R, et al. Design production and biocompatibility of nanostructured porous HAp and SiHAp ceramics as three dimensional scaffolds for stem cell culture and. Ceramics - Silikáty 2010;54:90-6.

[50] Leventouri T, Bunaciu CE, Perdikatsis V. Neutron powder diffraction studies of siliconsubstituted hydroxyapatite. Biomaterials 2003;24:4205-11. 
[51] López-Álvarez M, Solla EL, González P, Serra J, León B, Marques AP, et al. Siliconhydroxyapatite bioactive coatings ( $\mathrm{Si}-\mathrm{HA}$ ) from diatomaceous earth and silica. Study of adhesion and proliferation of osteoblast-like cells. Journal of Materials Science: Materials in Medicine 2009;20:1131-6.

[52] Martinez IM, Velasquez PN, De Aza PN. Synthesisans stability of a-tricalcium phosphate doped with dicalcium silicate in the system $\mathrm{Ca}_{3}\left(\mathrm{PO}_{4}\right)_{2}-\mathrm{Ca}_{2} \mathrm{SiO}_{4}$. Materials Characterization 2010;61:761-7.

[53] Porter AE, Patel N, Skepper JN, Best SM, Bonfield W. Comparison of in vivo dissolution processes in hydroxyapatite and silicon-substituted hydroxyapatite bioceramics. Biomaterials 2003;24:4609-20.

[54] Seet SL. Silicon-substituted calcium phosphate compounds - Synthesis characterizationa nd biological evaluation (Fumed silica). Science Asia 2009;35:255-60.

[55] Marques da Silva H, Mateescu M, Ponche A, Damia C, Champion E, Soares G, et al. Surface transformation of silicon-doped hydroxyapatite immersed in culture medium under dynamic and static conditions. Colloids and Surfaces B: Biointerfaces 2010;75:349-55.

[56] Sprio S, Tampieri A, Landi E, Sandri M, Martorana S, Celotti G, et al. Physico-chemical properties and solubility behaviour of multi-substituted hydroxyapatite powders containing silicon. Materials Science and Engineering: C 2008;28:179-87.

[57] Vandiver J, Dean D, Patel N, Botelho C, Best SM, Santos JD, et al. Silicon addition to hydroxyapatite increases nanoscale electrostatic, van der Waals, and adhesive interactions. Journal of Biomedical Materials Research Part A 2006;78A:352-63.

[58] Zou S, Ireland D, Brooks RA, Rushton N, Best S. The effects of silicate ions on human osteoblast adhesion, proliferation, and differentiation. Journal of Biomedical Materials Research Part B: Applied Biomaterials 2009;90B:123-30.

[59] Arcos D, Sanchez-Salcedo S, Izquierdo-Barba I, Ruiz L, Gonzalez-Calbet J, Vallet-Regí M. Crystallochemistry, textural properties, and in vitro biocompatibility of different silicondoped calcim phosphates. Journal of Biomedical Materials Research 2006;78A:762-71.

[60] Bakunova N, Fomin A, Fadeeva I, Barinov S, Shvorneva L. Silicon-containing hydroxylapatite nanopowders. Russian Journal of Inorganic Chemistry 2007;52:1492-7.

[61] Thian ES, Huang J, Best SM, Barber ZH, Bonfield W. Silicon-substituted hydroxyapatite: The next generation of bioactive coatings. Symposium A: Advanced Biomaterials International Conference on Materials for Advanced Technologies (ICMAT 2005) 2007;27:251-6.

[62] Huang T, Xiao Y, Wang S, Huang Y, Liu X, Wu F, et al. Nanostructured Si Mg $\mathrm{CO}_{3}$ Hydroxyapatite Coatings Deposited by Liquid Precursor Plasma Spraying. Journal of the thermal spray technology 2011;20:829-36.

[63] Gillespie P, Wu G, Sayer M, Stott MJ. Si complexes in calcium phosphate biomaterials. Journal of Materials Science: Materials in Medicine 2010;21:99-108.

[64] Langstaff S, Sayer M, Smith TJN, Pugh SM, Hesp SAM, Thompson WT. Resorbable bioceramics based on stabilized calcium phosphates. Part I: rational design, sample preparation and material characterization. Biomaterials 1999;20:1727-41.

[65] Reid JW, Pietak A, Sayer M, Dunfield D, Smith TJN. Phase formation and evolution in the silicon substituted tricalcium phosphate/apatite system. Biomaterials 2005;26:2887-97. 
[66] Sayer M, Stratilatov AD, Reid J, Calderin L, Stott MJ, Yin X, et al. Structure and composition of silicon-stabilized tricalcium phosphate. Biomaterials 2003;24:369-82.

[67] Borsa R-N. Elaboration de poudres et de dépôts de phosphates de caclium silicatés à usage de biomatériaux. Toulouse: Université de Toulouse; 2008.

[68] Aminian A, Solati-Hashjin M, Samadikuchaksaraei A, Bakhshi F, Gorjipour F, Farzadi A, et al. Synthesis of silicon-substituted hydroxyapatite by a hydrothermal method with two different phosphorous sources. Ceramics International 2011;37:1219-29.

[69] Kim YH, Song H, Riu DH, Kim SR, Kim HJ, Moon JH. Preparation of porous Siincorporated hydroxyapatite. Current Applied Physics 2005;5:538-41.

[70] Tian T, Jiang D, Zhang J, Lin Q. Synthesis of Si-substituted hydroxyapatite by a wet mechanochemical method. Materials Science and Engineering: C 2008;28:57-63.

[71] Solla EL, Gonzalez P, Serra J, Chuiussi S, Leon B, Garcia Lopez J. Pulsed laser deposition of silicon substituted hydroxyapatite coatings from synthetical and biological sources. Applied Surface Science 2007;254:1189-93.

[72] Xiao XF, Liu RF, Tang XL. Electrophoretic deposition of silicon substituted hydroxyapatite coatings from n-butanol-chloroform mixture. Journal of Materials Science: Materials in Medicine 2008;19:175-82.

[73] Panteix P-J, Bécahde E, Julien I, Abélard P, Bernache-Assollant D. Influence of anionic vacancies on the ionic conductivity of silicated rare earth apatites. Materials Research Bulletin 2008;43:1223-31.

[74] Bianco A, Cacciotti I, Lombardi M, Montanaro L. Si-substituted hydroxyapatite nanopowders: Synthesis, thermal stability and sinterability. Materials Research Bulletin 2009;44:345-54.

[75] Porter AE, Patel N, Skepper JN, Best SM, Bonfield W. Effect of sintered silicatesubstituted hydroxyapatite on remodelling processes at the bone-implant interface. Biomaterials 2004;25:3303-14.

[76] Marques PAAP, Magalhaes MCF, Correia RN, Vallet-Regí M. Synthesis and characterization of silicon-substituted hydroxyapatite. Key Engineering Materials 2001;192195:247-50.

[77] Plokhikh NV, Soin AV, Kuztnetsov AV, Veresov AG, Putlayev VI, Tretyakov YD. Synthesis of silico-substituted hydroxyapatite. Mendeleev Communications 2004;14:178-9.

[78] Mostafa NY, Hassan HM, Abd Elbader OH. Preparation and Characterization of $\mathrm{Na}^{+}$, $\mathrm{SiO}_{4}{ }^{4-}$, and $\mathrm{CO}_{3}{ }^{2-}$, Co-Substituted Hydroxyapatite. Journal of the American Ceramic Society 2011;94:1584-90.

[79] Mostafa NY, Hassan HM, Mohamed FH, Omar H. Preparation of $\mathrm{Na}^{+}, \mathrm{SiO}_{4}{ }^{4-}$ and $\mathrm{CO}_{3}{ }^{2-}$ co-substituted hydroxyapatite nanoparticles. Materials Research Bulletin 2009; In Press, Accepted Manuscript.

[80] Klein LC, Woodman RH. Porous silica by the Sol-Gel Process. Key Engineering Materials 1996;115:109-24.

[81] Elliott JC. Structure and Chemistry of the Apatites and Other Calcium Orthophosphates. Amsterdam-London-New York-Tokyo: Elsevier; 1994. 
[82] Sefcik J, McCormick V. Thermochemistry of aqueous silicate solution precursors to ceramics. Ceramics Processing 1997;43:2773-84.

[83] Lafon JP, Champion E, Bernache-Assollant D. Processing of AB-type carbonated hydroxyapatite $\mathrm{Ca} 10-\mathrm{x}(\mathrm{PO} 4) 6-\mathrm{x}(\mathrm{CO} 3) \mathrm{x}(\mathrm{OH}) 2-\mathrm{x}-2 \mathrm{y}(\mathrm{CO} 3) \mathrm{y}$ ceramics with controlled composition. Journal of the European Ceramic Society 2008;28:139-47.

[84] Rey C, Collins B, Goehl T, Dickson IR, Glimcher MJ. The carbonate environment in bone mineral: a resolution enhanced Fourier transform infrared spectroscopy study. Calcified Tissue International 1989;45:157-64.

[85] Mostafa NY, Hassan HM, Mohamed FH. Sintering behavior and thermal stability of $\mathrm{Na}^{+}$, $\mathrm{SiO}_{4}{ }^{4-}$ and $\mathrm{CO}_{3}{ }^{2-}$ co-substituted hydroxyapatites. Journal of Alloys and Compounds 2009;479:692-8.

[86] Marchat D, Bernache-Assollant D, Champion E. Cadmium fixation by synthetic hydroxyapatite in aqueous solution - Thermal behaviour. First International Conference on Engineering for Waste Treatment: Beneficial Use of Waste and By-Products (WasteEng2005) 2007;139:453-60.

[87] Stadelmann P. Java Electron Microscopy Simulation (JEMS) software. Switzerland: CIME-EPFL, École Polytechnique Fédérale de Lausanne; 1999-2006.

[88] Miquel JL, Facchini L, Legrand AP, Marchandise X, Lecouffe P, Chanavaz M, et al. Characterization of bioacceptable carbon materials. Clinical Materials 1990;5:115-25.

[89] Hartmann P, Barth S, Vogel J, Meyer K. Solid State NMR, X-Ray Diffraction, and Infrared Characterization of Local Structure in Heat-Treated Oxyhydroxyapatite Microcrystals: An Analog of the Thermal Decomposition of Hydroxyapatite during PlasmaSpray Procedure Journal of Solid State Chemistry 2001;160:460-8.

[90] Bonhomme C, Babonneau F, Azaïs T, Coelho C, Aimé C, Quignard S, et al. Dynamic Nuclear Polarization (DNP) for the characterization of nanoparticles. The Journal of Physical Chemistry 2012;(Submitted).

[91] Arends J, Christoffersen J, Christoffersen MR, Eckert H, Fowler BO, Heughebaert JC, et al. A calcium hydroxyapatite precipitated from an qaueous solution. Journal of Crystal Growth 1987;84.

[92] Rey C, Shimizu M, Collins B, Melvin JG. Resolution-enhanced Fourier transform infrared spectroscopy study of the environment of phosphate ions in the early deposits of a solid phase of calcium-phosphate in bone and enamel, and their evolution with age. 1: Investigations in the $\mathrm{n}_{4} \mathrm{PO}_{4}$ Domain. Calcified Tissue International 1990;46:384-94.

[93] Park E, Condrate SRA, Lee D, Kociba K, Gallagher PK. Characterization of hydroxyapatite: before and after plasma spraying. Journal of Materials Science 2002;13:2118.

[94] Rey C, Shimizu M, Collins B, Glimcher J. Resolution-enhanced Fourier transform infrared spectroscopy study of the environment of phosphate ions in the early deposits of a solid phase of calcium-phosphate in bone and enamel, and their evolution with age. 2: Investigations in the $\mathrm{n}_{3} \mathrm{PO}_{4}$ Domain. Calcified Tissue International 1991;49:383-8.

[95] Zymelka M, Marchat D, Szenknect S, Dacheux N, Bernache-Assollant D, Chevalier J. Silicon-substituted hydroxyapatite particles precipitation and dissolution. Acta Biomaterialia 2012;(Submitted). 
[96] Jillavenkatesa A, Condrate RA. The infrared and Raman spectra of b and a tricalcium phosphate $\left(\mathrm{Ca}_{3}\left(\mathrm{PO}_{4}\right)_{2}\right)$. Spectroscopy letters 1998;31:1619-34.

[97] Sänger AT, F. K. Structural disorder in hydroxyapatite. Zeitschrift für Kristallographie 1992;199:123-48.

[98] Hamilton WC, Ibers JA. Hydrogen Bonding in Solids. WA Benjamin : New-York 1968:204-21.

[99] Liao C-J, Lin F-H, Chen K-S, Sun J-S. Thermal decomposition and reconstitution of hydroxyapatite in air atmosphere. Biomaterials 1999;20:1807-13.

[100] Radin SR, Duchyene P. Plasma spraying induced changes of calcium phosphate ceramic characteristics and the effect on in vitro stability. Journal of Materials Science: Materials in Medicine 1992;3:33-42.

[101] Trombe J-C. Mise en évidence d'oxygène à différents degrés d'oxydation dans le réseau des apatites phosphocalciques et phosphostrontiques,. Annales de Chime 1973;8:335-47.

[102] Trombe J-C, Montel G. Some features of the incorportaion of oxygen in different oxidation states in the apatitic lattice - II on the synthesis and properties of calcium and strontium peroxiapatites

Journal of Inorganic and Nuclear Chemistry 1978;40:23-6.

[103] Wang T, Dorner-Reisel A, Müller E. Thermogravimetric and thermokinetic invetsigation of the dehydroxylation of hydroxyapatite powder. Journal of the European Ceramic Society 2004;24:693-8.

[104] Bernache-Assollant D, Ababou A, Champion E, Heughebaert M. Sintering of calcium phosphate hydroxyapatite $\mathrm{Ca}_{10}\left(\mathrm{PO}_{4}\right)_{6}(\mathrm{OH})_{2}$, I. Calcination and particle growth. Journal of the European Ceramic Society 2003;23:229-41.

[105] Liu Y, Shen Z. Dehydroxyalation of hydroxyapatite in dense bulk ceramics sintered by spark plasma sintering. ECERS 2012;32:2691-6.

[106] Trombe J-C, Montel G. Some features of the incorporation of oxygen in different oxidation states in the apatitic lattice - I. On the existence of calcium and strontium oxyapatite. Journal of Inorganic and Nuclear Chemistry 1978;40:15-21.

[107] Seuter AMJH. Existence Region of Calcium Hydroxyapatite and the

Equilibrium with Coexisting Phases at Elevated Temperatures. In: Anderson J.S RMW, Stone F.S., editor. Reactivity

of Solids1972.

[108] Heughebaert JC. Contribution à l'étude de l'évolution des orthophosphates de calcium précipités amorphes en orthophosphates apatitiques [Sciences physiques]. Toulouse: Institut National Polytechnique; 1977.

[109] Heughebaert JC, Montel G. Étude de l'évolution de l'orthophosphate tricalcique non cristallin en phosphate apatitique à la faveur d'une réaction chimique à température ordinaire. Revue de Physique Appliquée 1977;12:691-4.

[110] Aguiar H, Serra J, González P, León B. Structural study of sol-gel silicate glasses by IR and Raman spectroscopies. Journal of Non-Crystalline Solids 2009;355:475-80. 
[111] Guerrero A, Goni S, A. M, Dolado JS. Microstructure and mechanical performance of Belite cements from high calcium coal fly ash. Journal of American Ceramic Society 2005;88:1845-53.

[112] Hollenstein C, Howling AA, Courteille C, Magni D, M. SS, Kroesen GMW, et al. Silicon oxide particle formation in RF plasmas investigated by infrared absorption spectroscopy and mass spectrometry. Journal of Physics D: Applied Physics 1998;31:74-84.

[113] Dunfield D, Sayer M, Shurvell HF. Total Attenuated Reflection Infrared Analysis of Silicon-Stabilized Tri-Calcium Phosphate. The Journal of Physical Chemistry B 2005;109:1957919583-19583.

[114] Al-Oweini R, El-Rassy H. Synthesis and characterization by FTIR spectroscopy of silica aerogels prepared using several $\mathrm{Si}(\mathrm{OR}) 4$ and $\mathrm{R}^{\prime \prime} \mathrm{Si}\left(\mathrm{OR}^{\prime}\right) 3$ precursors. Journal of Molecular Structure 2009;919:140-5.

[115] Fidalgo A, Ilharco LM. The defect structure of sol-gel derived silica/polytetrahydrofuran hybrid films by FTIR. Journal of Non-Crystalline Solids 2001;283:144-54.

[116] Gopal NO, Narasimhulu KV, Rao JL. EPR, optical, infrared and Raman spectral studies of Actinolite mineral. Spectrochimica Acta 2004;60:2441-8.

[117] Alekhina LG, Akhmanova MV, Dement'ev VA, Gribov LA. Solution of the inverse spectroscopic problem for the SiO4 group. Journal of Applied Spectroscopy 1975;22:546-9.

[118] Bensted J, Varma SP. Some applications of infrared and Raman spectroscopy in cement chemistry. Part 2 - Portland cement and its constituents. Cement Technology 1974;4:378-82.

[119] Dutta PK, Shieh D-C. Raman Spectarl Study of the composition of basic silicate solutions. Applied Spectroscopy 1985;39:343-6.

[120] Etchepare J. Interprétation des spectres de diffusion Raman de verres de silice binaires. Spectrochimica Acta 1970;26A:2147-54.

[121] Mollah MYA, Yu W, Schennach R, Cocke DL. A fourier transform infrared spectroscopic investigation of the early hydration of Portland cement and the influence of sodium lignosulfonate. Cement and concrete research 2000;30:267-73.

[122] Nakamura M, Mochizuki Y, usami K, Y. I, T. N. Infrared absorption spectra and compositions of evaporated silicon oxides $\left(\mathrm{SiO}_{\mathrm{x}}\right)$. Solid State Communications 1984;50:107981.

[123] Theil JA, Tsu DV, Watkins MW, Kim SS, Lucovsky G. Local bonding environment of $\mathrm{Si}-\mathrm{OH}$ groups in $\mathrm{SiO}_{2}$ deposited by remote plasma-enhanced chemical vapor deposition and incorporated by postdeposition exposure to water vapor. American Vacuum Society 1990;A8:1374-81.

[124] Socrates G. Infrared and Raman characteristic group frequencies : Tables and Charts2004.

[125] Bell RJ, Bird NF, Dean P. The vibrational spectra of vitreous silica, germania and beryllium fluoride Journal of Physics C: Solid State Physics 1968;1:299-303.

[126] Sato RK, McMillan PF. An infrared and Raman study of the isotopic species of alphaquartz. The Journal of Physical Chemistry B 1987;91:3494-8. 
[127] Sitarz M, Handke M, Mozgawa W. Identification of silicooxygen rings in $\mathrm{SiO}_{2}$ based on IR spectra. Spectrochimica Acta Part A: Molecular and Biomolecular Spectroscopy 2000;56:1819-23.

[128] Ahsan MR, Mortuza MG. Infrared spectra of $\mathrm{xCaO}(1-\mathrm{x}-\mathrm{z}) \mathrm{SiO}_{2} \mathrm{zP}_{2} \mathrm{O}_{5}$ glasses. Journal of Non-Crystalline Solids 2005;351:2333-40.

[129] Bosomworth DR, Hayes W, Spray ARL, Watkins GD. Absorption of Oxygen in Silicon in the Near and the Far Infrared Proceedings of the Royal Society (London) 1970;317:133-52.

[130] Sari SO, Hollingsworth-Smith P, Oona H. Near IR absorption in films of silicon containing oxygen. Journal of Physics and Chemistry of Solids 1978;39:857. 


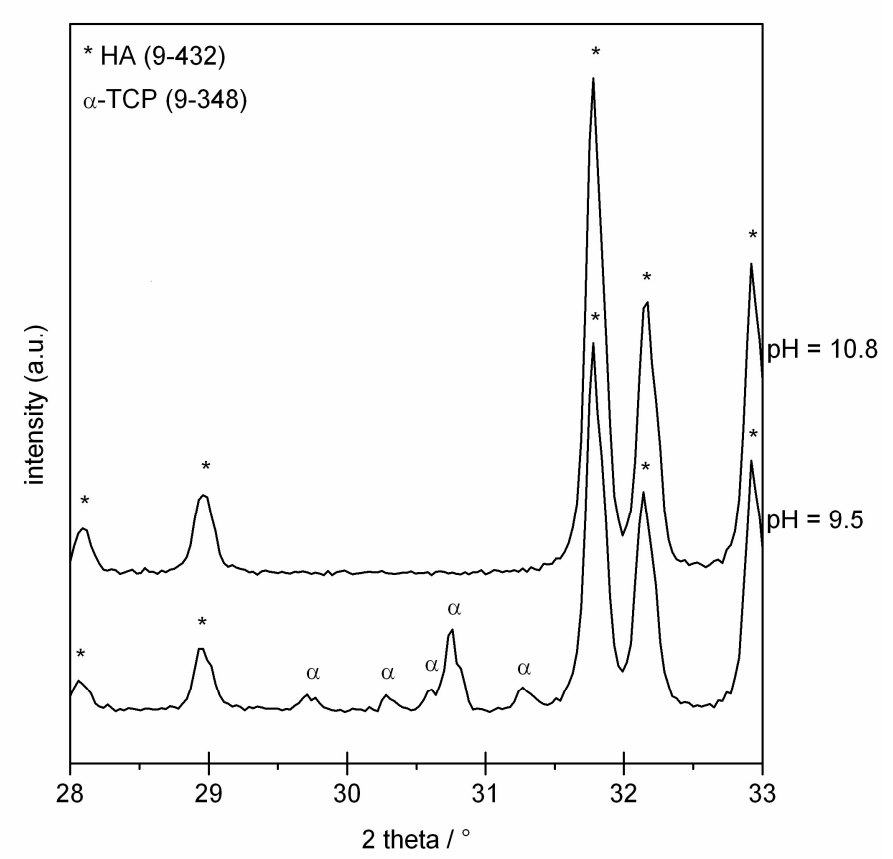

Fig. 1. XRD patterns of heat treated $\mathrm{Si}_{0.50} \mathrm{HA}$ powders prepared at $5 \mathrm{O}^{\circ} \mathrm{C}$ and maintained at $\mathrm{pH}$ 9.5 and 10.8 .

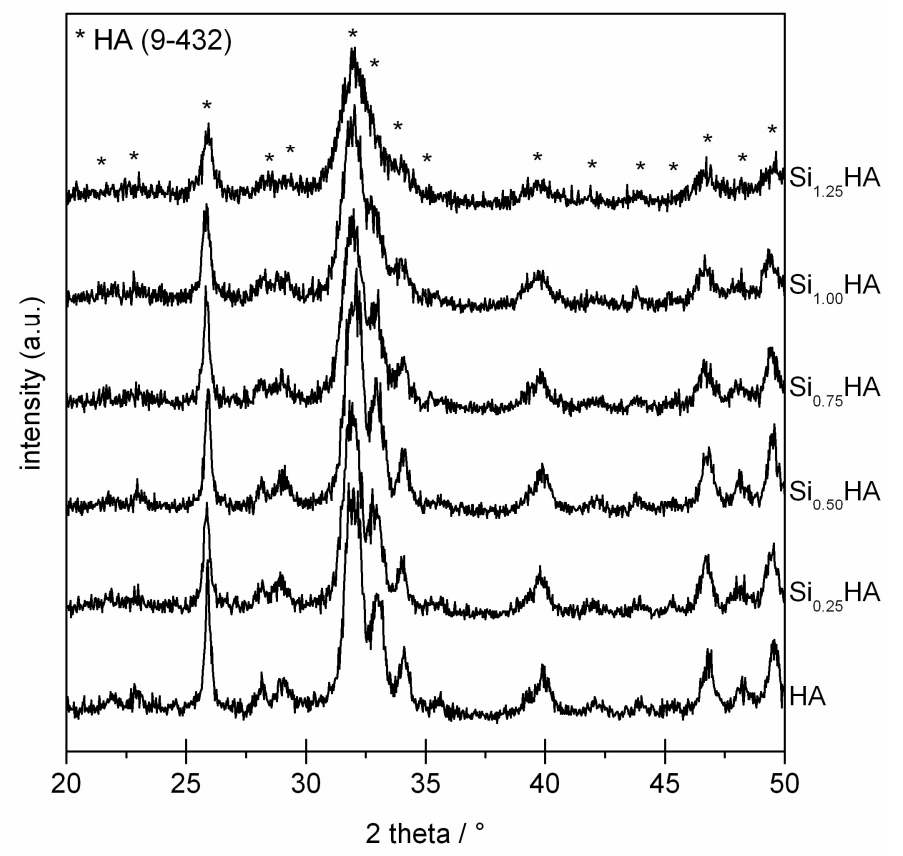

Fig. 2. X-ray diffraction patterns of raw SiHA powders synthesized at $\mathrm{pH}=10.8$ with different silicon concentration. 


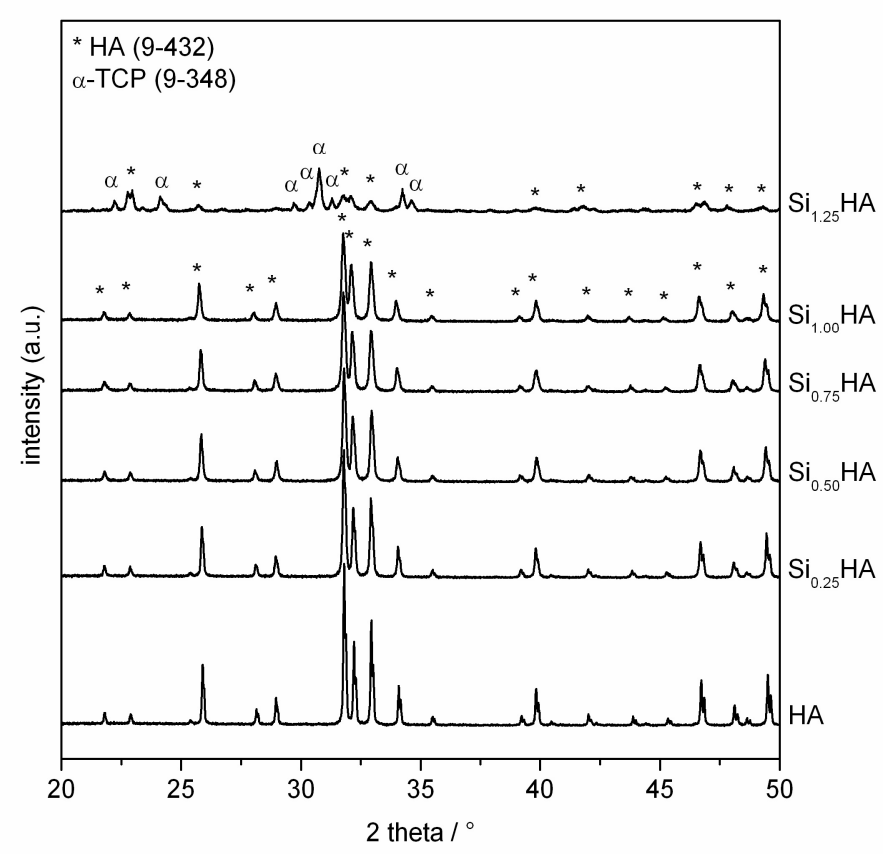

Fig. 3. X-ray diffraction patterns of heat treated $\left(1000^{\circ} \mathrm{C} / 15 \mathrm{~h}\right) \mathrm{SiHA}$ powders synthesized at $\mathrm{pH}=10.8$ with different silicon concentration.

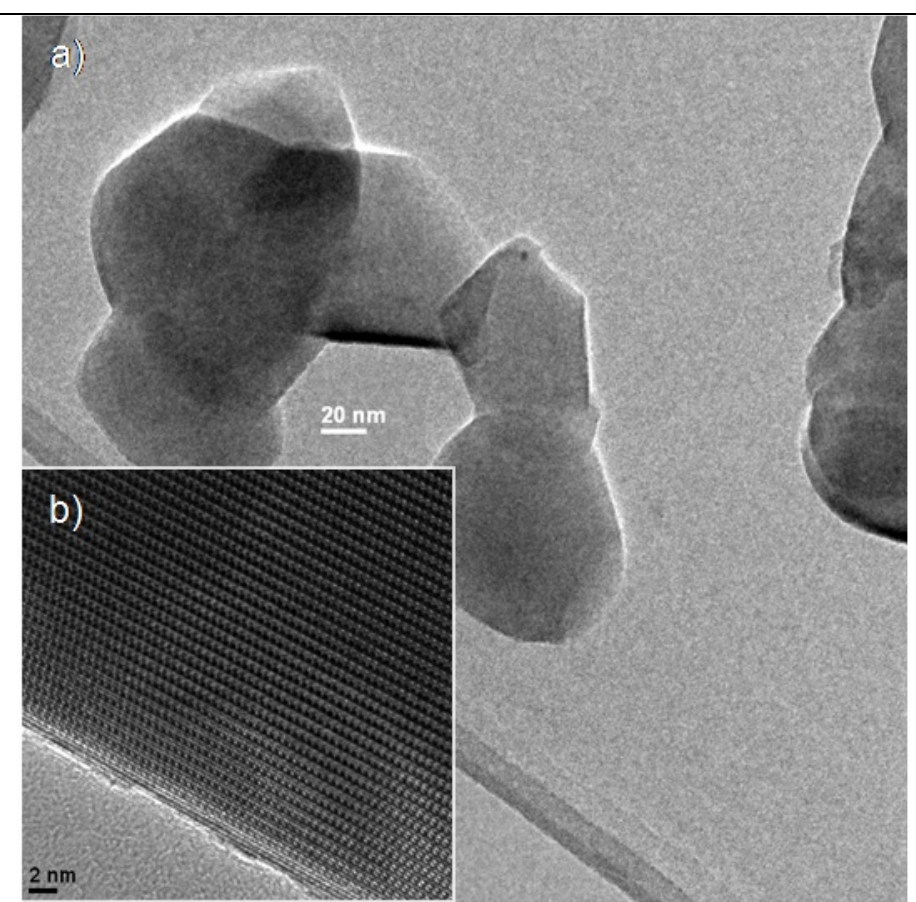

Fig. 4: (a) TEM micrograph of heat treated $\mathrm{Si}_{1.0} \mathrm{HA}$ crystallites $\left(1000^{\circ} \mathrm{C} / 15 \mathrm{~h}\right)$, (b) Highresolution lattice image of a heat treated $\mathrm{Si}_{1.0} \mathrm{HA}$ particle $\left(1000^{\circ} \mathrm{C} / 15 \mathrm{~h}\right)$ along the zone axis [01-1]; plane spacing of $8.2 \AA$. 


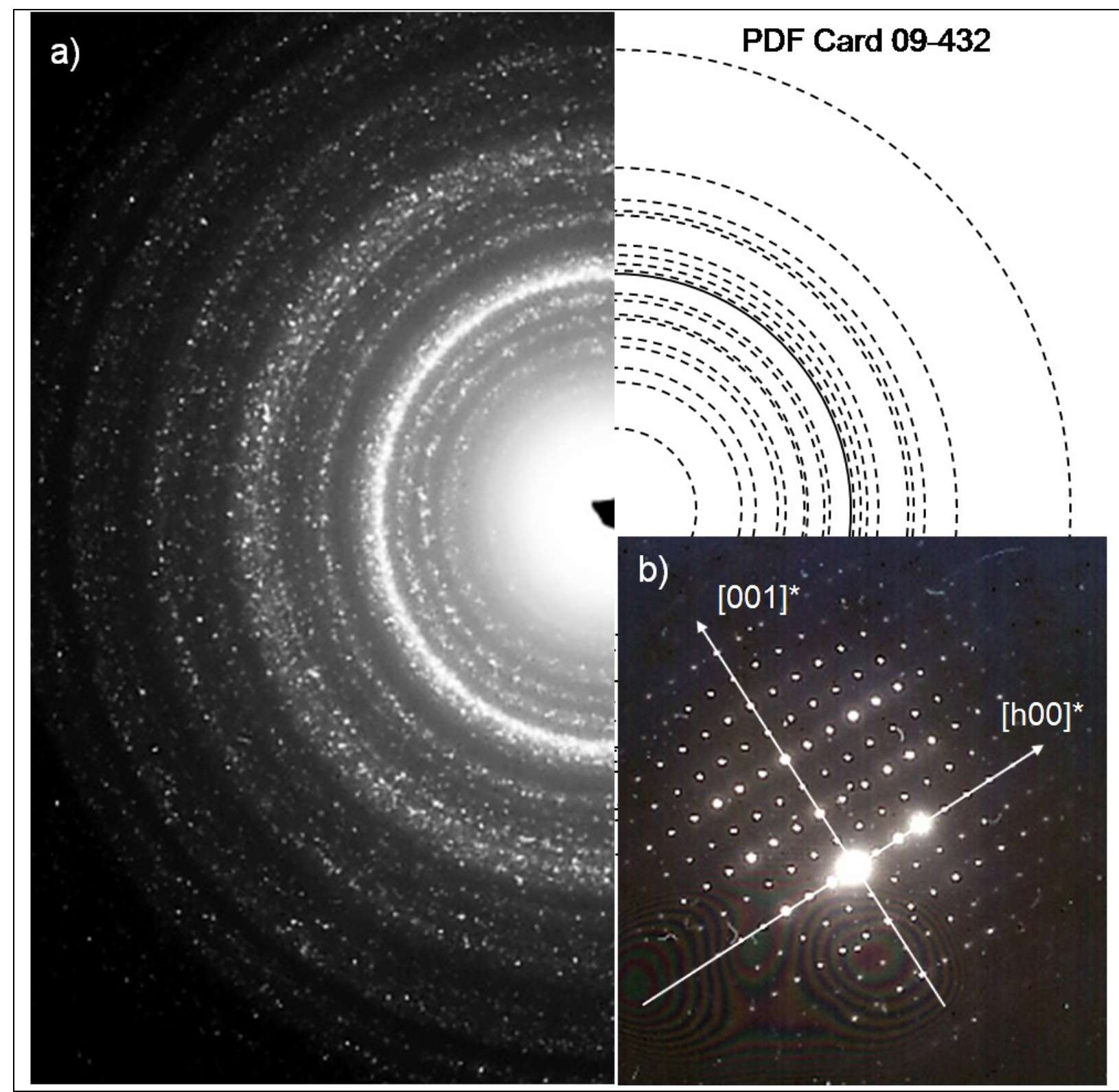

Fig. 5: (a) selected area electron diffraction (SAED) pattern of heat treated $\mathrm{Si}_{1.0} \mathrm{HA}$ powder $\left(1000^{\circ} \mathrm{C} / 15 \mathrm{~h}\right)$, (b) SAED of heat treated $\mathrm{Si}_{1.0} \mathrm{HA}$ powder $\left(1000^{\circ} \mathrm{C} / 15 \mathrm{~h}\right)$ for the $[01 \mathrm{o}$ zone axis, $c / a=0.730$ 

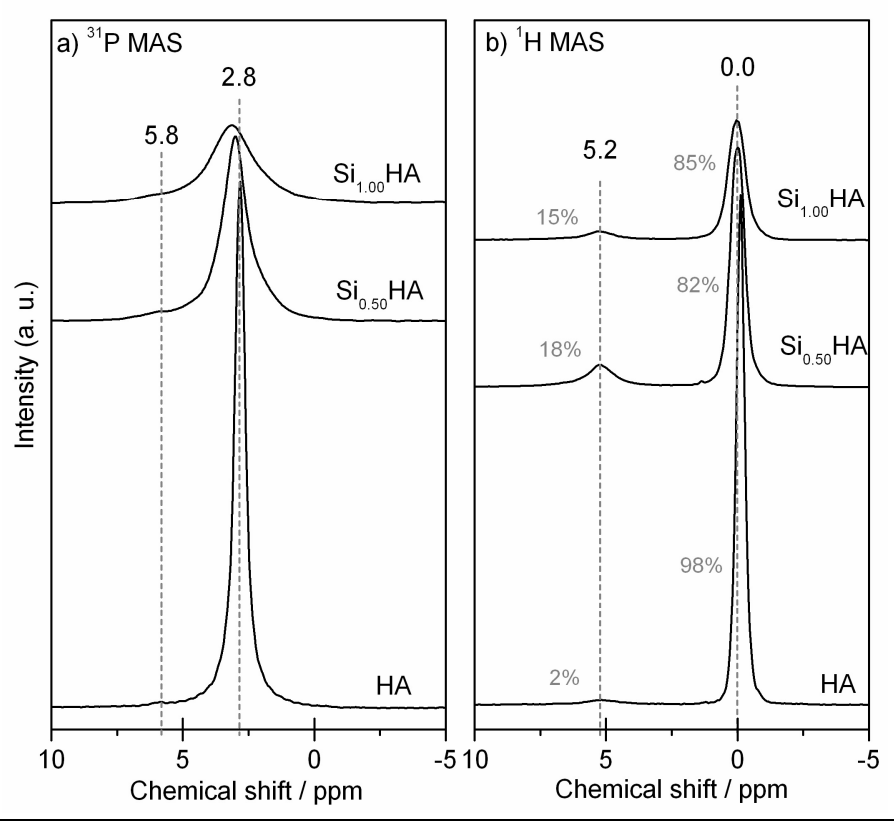

Fig. 6. (a) ${ }^{11} \mathrm{P}$ and (b) ${ }^{1} \mathrm{H}$ MAS-NMR spectra of the $\mathrm{HA}, \mathrm{Si}_{0.50} \mathrm{HA}$ and $\mathrm{Si}_{1.00} \mathrm{HA}$ powders calcined at $1000^{\circ} \mathrm{C}$ for $15 \mathrm{~h}$.

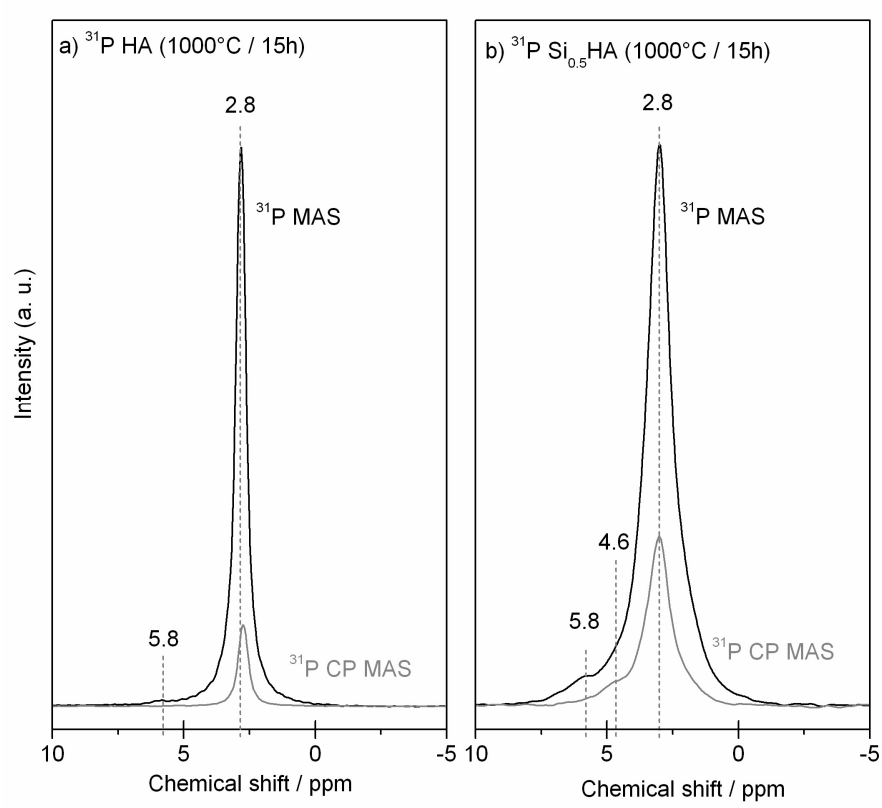

Fig. 7. Comparison between ${ }^{31} \mathrm{P}$ MAS-NMR and CP MAS NMR spectra of (a) HA and (b) $\mathrm{Si}_{0.50} \mathrm{HA}$ powders calcined at $1000^{\circ} \mathrm{C}$ for $15 \mathrm{~h}$. 


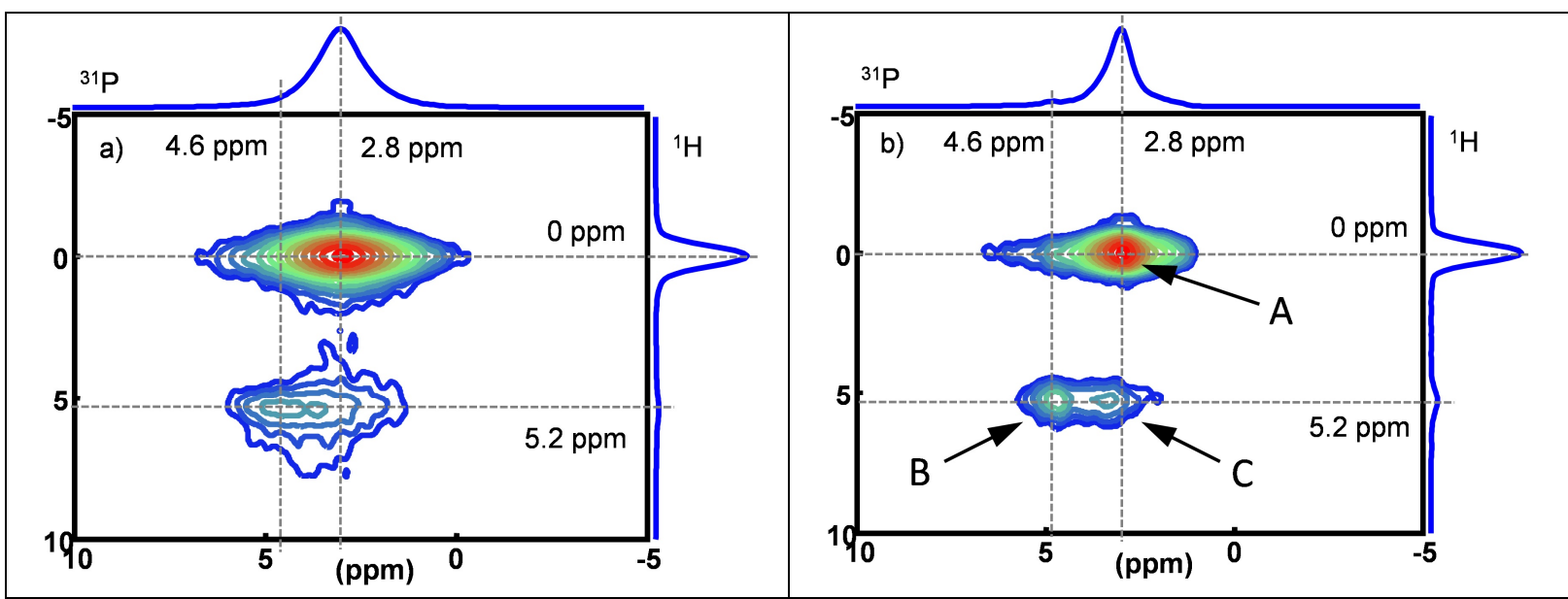

Fig. 8. ${ }^{1} \mathrm{H}-31$ P HETCOR CP MAS experiment recorded on (a) $\mathrm{Si}_{1.00} \mathrm{HA}$ powder calcined at $400^{\circ} \mathrm{C}$ for $2 \mathrm{~h}$, and (b) $\mathrm{Si}_{0.50} \mathrm{HA}$ powder calcined at $1000^{\circ} \mathrm{C}$ for $15 \mathrm{~h}$.

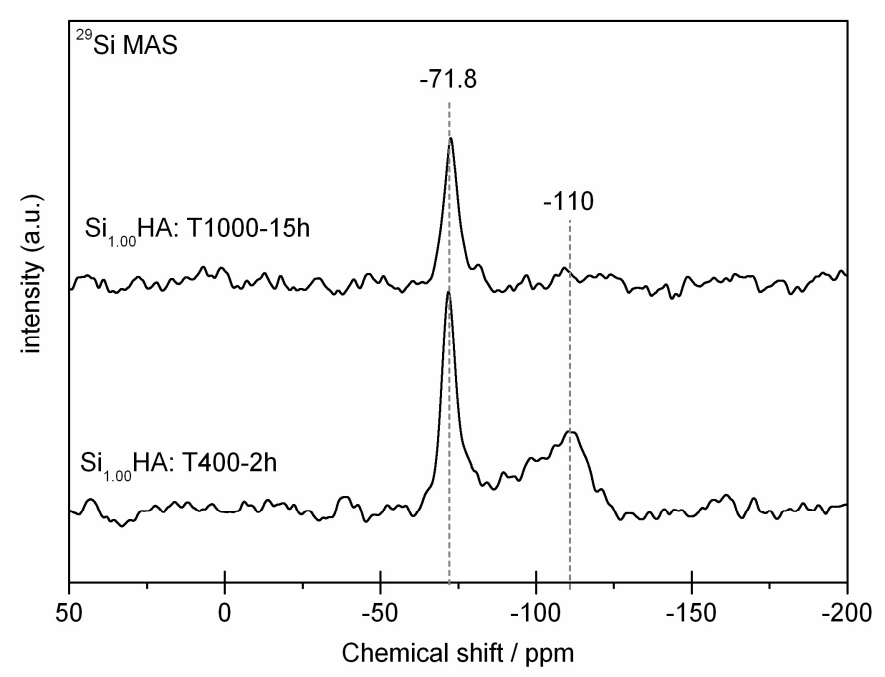

Fig. 9. ${ }^{29} \mathrm{Si}$ MAS-NMR spectra of the $\mathrm{Si}_{1.00} \mathrm{HA}$ powder calcined at $400^{\circ} \mathrm{C}$ for $2 \mathrm{~h}$ and $1000^{\circ} \mathrm{C}$ for $15 \mathrm{~h}$ 


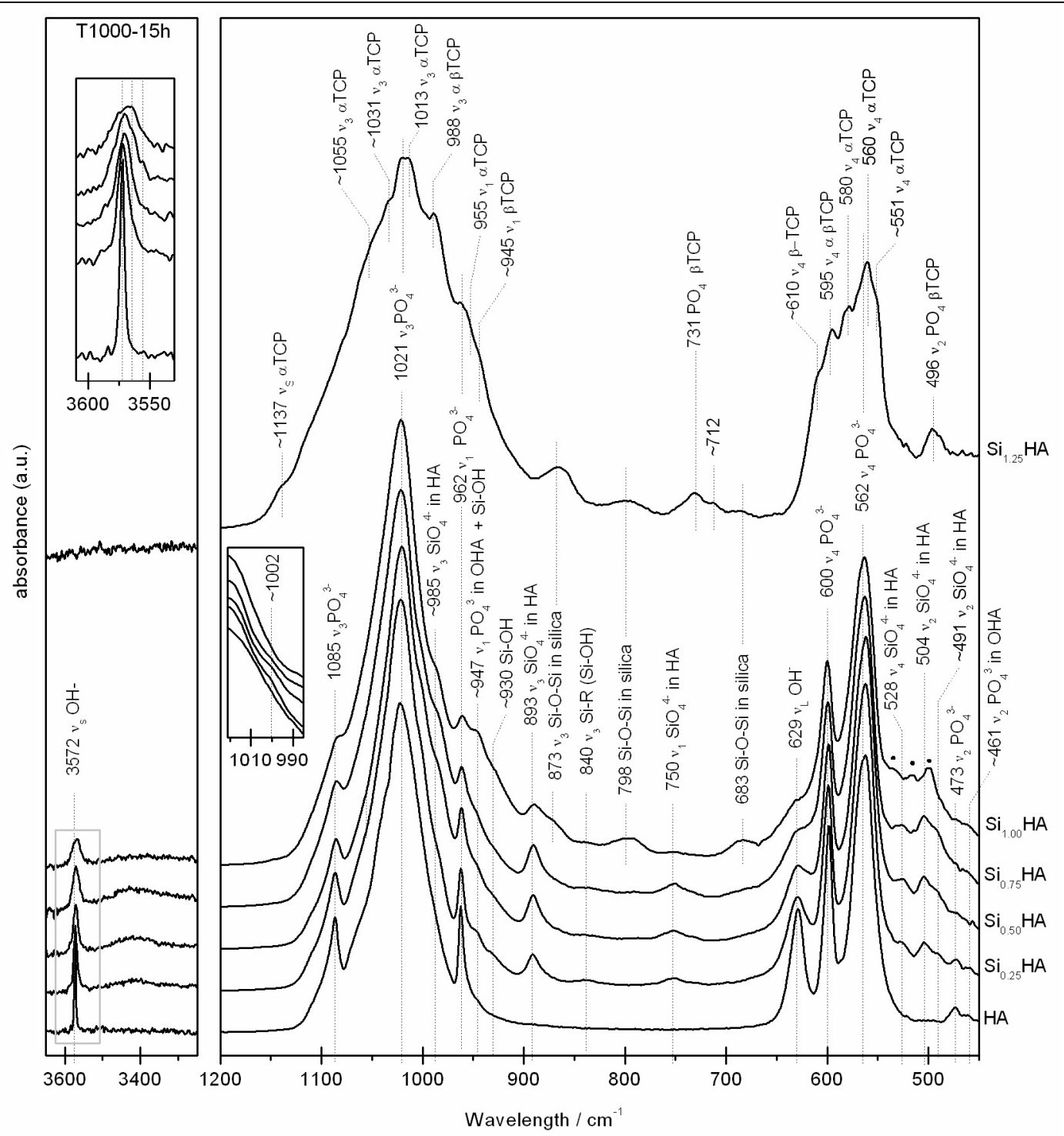

Fig. 10. FTIR spectra of calcined HA and SiHA powders $\left(1000^{\circ} \mathrm{C} / 15 \mathrm{~h}\right)$ collected at room temperature, symbol $\bullet$ shows additional vibrations for $\mathrm{Si}_{1.0} \mathrm{HA}$ at $500,515,535 \mathrm{~cm}^{-1}$.

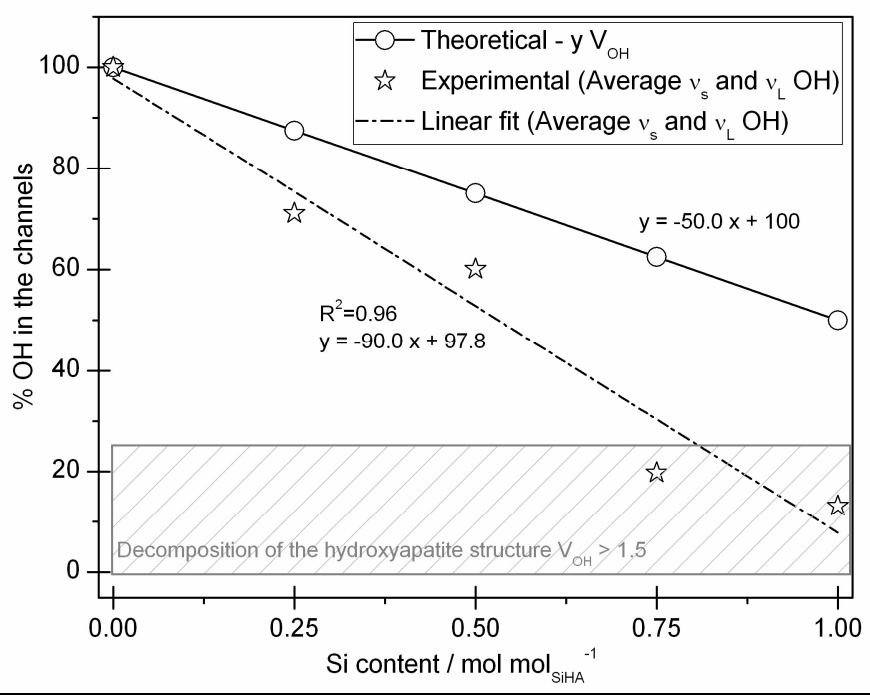

Fig. 11. OH content into the apatitic channels versus the Si content, for theoretical SiHA structure $\left(y \mathrm{~V}_{\mathrm{OH}}\right)$ and samples calcined at $1000^{\circ} \mathrm{C}$ for $15 \mathrm{~h}$ (determined from integrated areas 


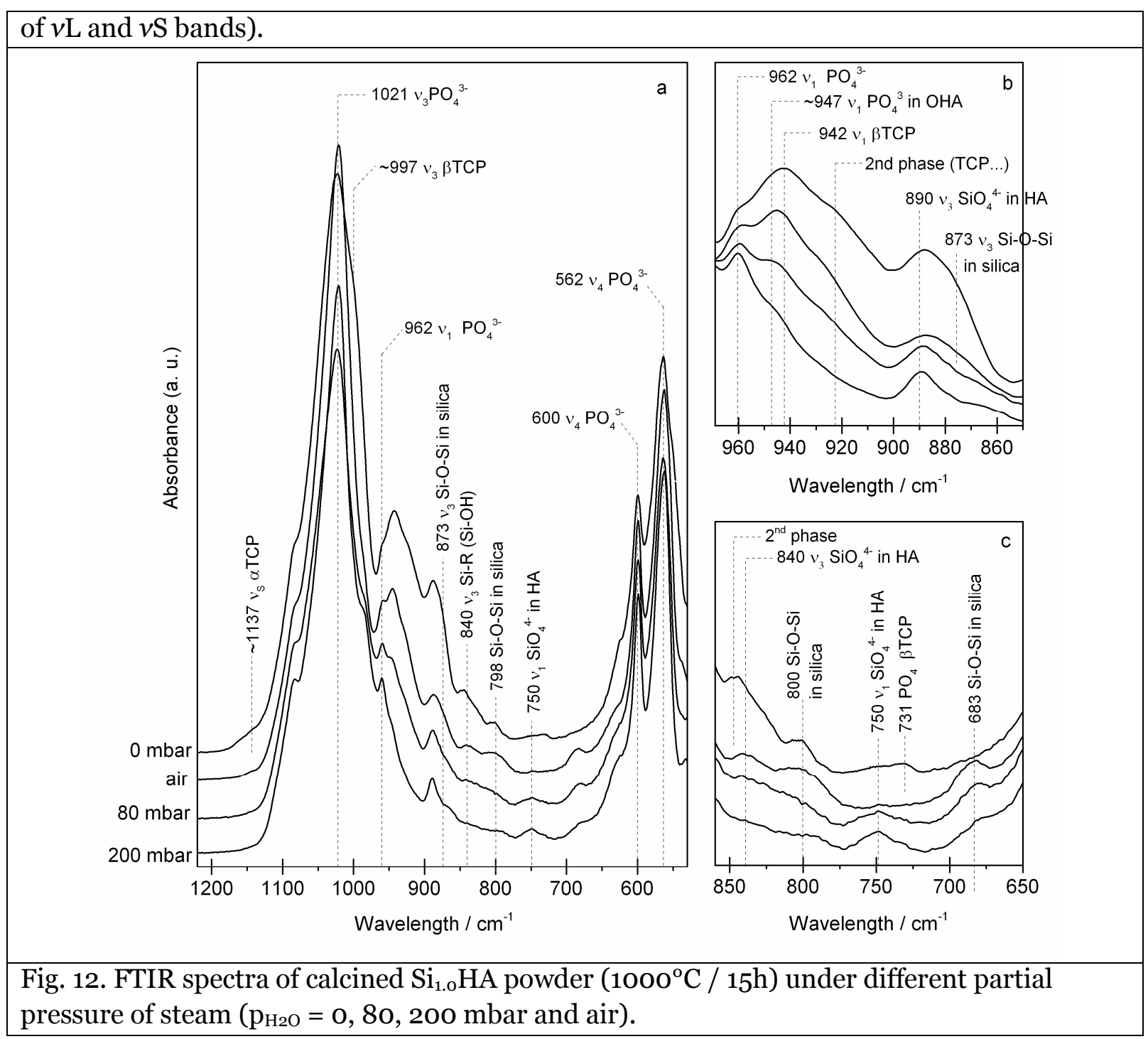


Table 1

Chemical conditions of preparation of $\mathrm{HA}$ and $\mathrm{Si}_{y} \mathrm{HA}$ samples and final composition of the calcined powders $\left(1000^{\circ} \mathrm{C} / 15 \mathrm{~h}\right)$.

\begin{tabular}{|c|c|c|c|c|c|c|c|c|}
\hline \multirow{4}{*}{ Sample } & \multicolumn{5}{|c|}{$\begin{array}{l}\text { Synthesis parameters } \\
\left(\mathrm{T}=50^{\circ} \mathrm{C}, \mathrm{t}_{\mathrm{m}}=24 \mathrm{~h}\right)\end{array}$} & \multicolumn{3}{|c|}{ Composition of the final calcined powders $\left(1000^{\circ} \mathrm{C} / 15 \mathrm{~h}\right)$} \\
\hline & $\mathrm{n}_{\mathrm{Ca}}$ & $\mathrm{n}_{\mathrm{P}}$ & $\mathrm{n}_{\mathrm{Si}}$ & $\mathrm{pH}$ & $\mathrm{y}_{\mathrm{Si}}$ & $\mathrm{y}_{\mathrm{Si}}$ & Chemical formula of $\mathrm{Si}_{\mathrm{y}} \mathrm{HA}$ & $\mathrm{Ca} /(\mathrm{P}+\mathrm{Si})$ \\
\hline & & & & & Expected & \multicolumn{2}{|c|}{ Determined - According to Equation Eq. 2} & Determined hy \\
\hline & $/ \mathrm{mol}$ & $/ \mathrm{mol}$ & / mol & - & \multicolumn{2}{|c|}{$/ \mathrm{mol} \mathrm{mol}^{-1} \mathrm{SiHA}$} & - & ICP/AES \\
\hline HA & 0.200 & 0.120 & 0 & 9.5 & 0 & 0 & $\mathrm{Ca}_{10}\left(\mathrm{PO}_{4}\right)_{6}(\mathrm{OH})_{2}$ & $1.69 \pm 0.05$ \\
\hline $\mathrm{Si}_{0.25} \mathrm{HA}$ & 0.200 & 0.115 & 0.005 & 11.0 & 0.25 & $0.28 \pm 0.02$ & $\mathrm{Ca}_{10}\left(\mathrm{PO}_{4}\right)_{5.72}\left(\mathrm{SiO}_{4}\right)_{0.28}(\mathrm{OH})_{1.72}\left(\mathrm{~V}_{\mathrm{OH}}\right)_{0.28}$ & $1.69 \pm 0.02$ \\
\hline $\mathrm{Si}_{0.50} \mathrm{HA}$ & 0.200 & 0.110 & 0.010 & 9.5 & 0.50 & N/A & $\mathrm{HA}+\alpha \mathrm{TCP}$ & N/A \\
\hline $\mathrm{Si}_{0.50} \mathrm{HA}$ & 0.200 & 0.110 & 0.010 & 11.0 & 0.50 & $0.52 \pm 0.02$ & $\mathrm{Ca}_{10}\left(\mathrm{PO}_{4}\right)_{5.48}\left(\mathrm{SiO}_{4}\right)_{0.52}(\mathrm{OH})_{1.48}\left(\mathrm{~V}_{\mathrm{OH}}\right)_{0.52}$ & $1.68 \pm 0.02$ \\
\hline $\mathrm{Si}_{0.75} \mathrm{HA}$ & 0.200 & 0.105 & 0.015 & 11.0 & 0.75 & $0.72 \pm 0.02$ & $\mathrm{Ca}_{10}\left(\mathrm{PO}_{4}\right)_{5.28}\left(\mathrm{SiO}_{4}\right)_{0.72}(\mathrm{OH})_{1.28}\left(\mathrm{~V}_{\mathrm{OH}}\right)_{0.72}$ & $1.67 \pm 0.03$ \\
\hline $\mathrm{Si}_{1.00} \mathrm{HA}$ & 0.200 & 0.100 & 0.020 & 11.0 & 1.00 & $0.97 \pm 0.02$ & $\mathrm{Ca}_{10}\left(\mathrm{PO}_{4}\right)_{5.03}\left(\mathrm{SiO}_{4}\right)_{0.97}(\mathrm{OH})_{1.03}\left(\mathrm{~V}_{\mathrm{OH}}\right)_{0.97}$ & $1.67 \pm 0.01$ \\
\hline $\mathrm{Si}_{1.25} \mathrm{HA}$ & 0.200 & 0.095 & 0.025 & 11.0 & 1.25 & N/A & $\mathrm{HA}+\mathrm{TCP}$ & N/A \\
\hline
\end{tabular}


Table 2

NMR parameters.

\begin{tabular}{|c|c|c|c|c|c|c|}
\hline \multirow[t]{2}{*}{ NMR Experiments } & $\mathrm{t}_{90^{\circ}}$ & $\begin{array}{l}\text { number } \\
\text { of scans }\end{array}$ & $\begin{array}{c}\text { relaxation } \\
\text { delay }\end{array}$ & $\begin{array}{c}{ }^{1} \mathrm{H} \\
\text { decoupling }\end{array}$ & $\begin{array}{l}\text { contact } \\
\text { time }\end{array}$ & $\begin{array}{c}t_{1} \\
\text { increments }\end{array}$ \\
\hline & $/ \mu \mathrm{s}$ & - & $/ \mathrm{s}$ & - & $/ \mathrm{ms}$ & \\
\hline${ }^{1} \mathrm{H}$ MAS & 4.6 & 4 & 300 & - & - & - \\
\hline${ }^{31} \mathrm{P}$ MAS & 1.3 & 16 & 60 & \multirow{3}{*}{$\begin{array}{l}\text { SPINAL-64 } \\
(54 \mathrm{kHz})\end{array}$} & - & - \\
\hline${ }^{31} \mathrm{P}$ CPMAS & \multirow[b]{2}{*}{1.5} & 16 & \multirow[b]{2}{*}{15} & & 3 & - \\
\hline $\begin{array}{c}{ }^{1} \mathrm{H}^{-31} \mathrm{P} \text { HETCOR } \\
\text { CPMAS }\end{array}$ & & 32 & & & 1 & 128 \\
\hline${ }^{29} \mathrm{Si}$ MAS & 1.5 & $\sim 4000$ & 60 & $\begin{array}{c}\text { SPINAL-64 } \\
(45 \mathrm{kHz})\end{array}$ & - & - \\
\hline
\end{tabular}


Table 3.

Lattice parameters, unit cell volume and mean size of the crystallites of heat-treated powders at $1000^{\circ} \mathrm{C}$ for $15 \mathrm{~h}$ evaluated by Rietveld refinement.

\begin{tabular}{|l|l|l|l|l|}
\hline \multirow{2}{*}{ Sample } & \multicolumn{2}{|l|}{ Lattice parameters $/ \AA$} & \multirow{2}{*}{ Volume of the unit cell / $\AA^{3}$} & \multirow{2}{*}{ Crystallites mean size / nm } \\
\cline { 2 - 3 } & a-axis & c-axis & & \\
\hline PDF 9-432 & 9.418 & 6.884 & 1058 & - \\
\hline $\mathrm{HA}$ & $9.421 \pm 310^{-5}$ & $6.884 \pm 310^{-5}$ & $1058 \pm 1$ & $243 \pm 1$ \\
\hline $\mathrm{Si}_{0,25} \mathrm{HA}$ & $9.423 \pm 410^{-5}$ & $6.892 \pm 410^{-5}$ & $1060 \pm 1$ & $157 \pm 1$ \\
\hline $\mathrm{Si}_{0,50} \mathrm{HA}$ & $9.428 \pm 210^{-4}$ & $6.899 \pm 210^{-4}$ & $1062 \pm 1$ & $116 \pm 1$ \\
\hline $\mathrm{Si}_{0,75} \mathrm{HA}$ & $9.423 \pm 210^{-4}$ & $6.908 \pm 210^{-4}$ & $1062 \pm 1$ & $103 \pm 1$ \\
\hline $\mathrm{Si}_{1,00} \mathrm{HA}$ & $9.416 \pm 710^{-5}$ & $6.920 \pm 510^{-5}$ & $1063 \pm 1$ & $107 \pm 1$ \\
\hline
\end{tabular}


Table 4

IR bands and shoulders assignment proposed by our work

\begin{tabular}{|l|l|l|}
\hline$\lambda / \mathrm{cm}^{-1}$ & Mode assignments proposed by this work & Literature support \\
\hline $1002 *$ & Degenerated $\mathrm{PO}_{4}{ }^{3-}$ asymmetric stretching $\left(v_{3}\right)$ & {$[94,110]$} \\
\hline 985 & Si-OH at SiHA surface / and/or / Si in SiHA & {$[110-112]$} \\
\hline \multirow{2}{*}{947} & Oxyapatite & {$[93,99,100,102,113]$} \\
\cline { 2 - 3 } & Si-OH at SiHA surface & {$[114-116]$} \\
\hline $930 * *$ & Si-OH at SiHA surface / and/or / Si in SiHA & {$[114,117-121]$} \\
\hline 893 & Si in SiHA & {$[8,113,118]$} \\
\hline 873 & Si in silica & {$[112,113,122,123]$} \\
\hline 840 & Si-R & {$[118,124]$} \\
\hline 798 & Si in silica & {$[34,110,112-115,117,120,122,125-127]$} \\
\hline 750 & Si in SiHA & {$[32,54,74]$} \\
\hline 683 & Si in silica & {$[113,114,116,126,127]$} \\
\hline 535 & Si in silica & {$[128]$} \\
\hline 528 & Si in SiHA & {$[111,118,121,128]$} \\
\hline 515 & Si in silica & {$[32,56,118]$} \\
\hline 504 & Si in SiHA & \\
\hline
\end{tabular}

* degeneration of the $v_{3} \mathrm{PO}_{4}{ }^{3-}$ domain at $1020 \mathrm{~cm}^{-1}$ due to the $\mathrm{SiO}_{4}{ }^{4-}$ in the environment of the phosphate ions

** degeneration of the band at $947 \mathrm{~cm}^{-1}$ 